\title{
المكان في شعر ابن شهيد \\ الأندلسسي (قرطبة نموذجًا)
}

إيمان أنورحسن علي

دكتوراه في الأدب الأندلسسي- جمهورية مصر العربية

emaanhassan615@gmail.com 


$$
\text { المجلة الدولية للدراسـات اللغوية والأدبية العربية }
$$

International Journal for Arabic Linguistics and Literature Studies (JALLS)

\section{www.refaad.com}

Journal Homepage: https://www.refaad.com/views/JALS/home.aspx ISSN: 2663-5860(Online) 2663-5852(Print)

$$
\begin{aligned}
& \text { المكان في شعر ابن شهيد الأندلسي (قرطبة نموذجًا) } \\
& \text { إيمان أنورحسن علي } \\
& \text { دكتوراه في الأدب الأندلسي- جمهورية مصر العربية } \\
& \text { emaanhassan615@gmail.com }
\end{aligned}
$$

DOI: https://doi.org/10.31559/JALLS2021.3.2.2 2021/6/27 2021/3/21 مراجعة البحث: 2021/5/26 قبول البحث

للمكان تأثير على الإنسان بوجاه عام، وعلى الشاعر بوجه خاص؛ سواء بمفرداته الظاهرة للعيان، والتي عايشها ونما بين تفاصيلها، أو بما أفرزته تلك الأماكن من مشاعر إيجابية وأخرى سلبية صاحبتهاه عبر رحلته الحياتياة.

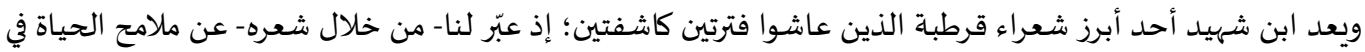
قرطبة في يسرها ورخائها واستقرارها، كما عبّر عن فترة المحندة وما تمخض عنها من تشريد للناس وخراب للحياة والعمران.

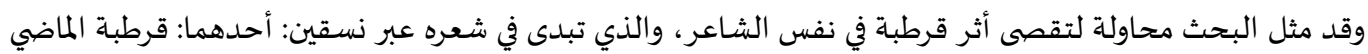
والحاضر، والثاني: قرطبة المكان الأليف والمكان المعادي.

وقد توسلت تلك الرؤى أدوات ووسائط استطاعت حمل رسالة الشاعر، وخلق خطاب شعري ملائم؛ فكانت الاستعارة والكناية أعمدة في استكناه معاني الشاعر، وتجسيم تجربته، وتشخيصها، والإيحاء بها. وكان رسم الصيور الحسياة- البصرية

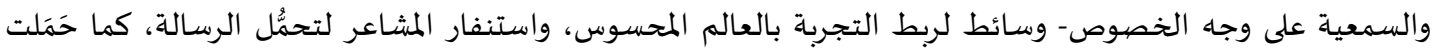

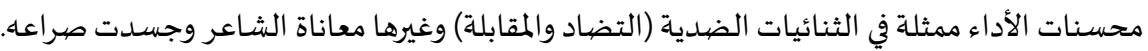

هذا، وقد عكست ثقافة الشـاعر لغة مكانية ذات مستويات متعددة، وبدت موسيقاه- بما حملتهاه من تنوع نغماتها، وملاءمة موسيقاها- أكثر قدرة على استيعاب دقائق التجربة، والبوح بها، والتعبير عنها. الكلمات المفتاحية: المكان؛ الخيال؛ الصورة الشعرية؛ الاستعارة؛ التجسيم؛ التشخيص؛ الكناية.

$$
\begin{aligned}
& \text { تمهييد } \\
& \text { ( ليست الأرض مجرد مشايهة للسماء المليئة بالنجوم، }
\end{aligned}
$$

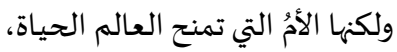

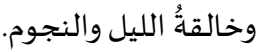

$$
\begin{aligned}
& \text { الأم - الأرض ) أريك نويمان (بلاشلار، 1987) }
\end{aligned}
$$

أجمعت الأديان- والأساطير قبلها- على أن الطين هو العنصر الأول المكون لخلق الإنسان، وقد أثبت ذلك العلم الحديث؛ إذ ثمة

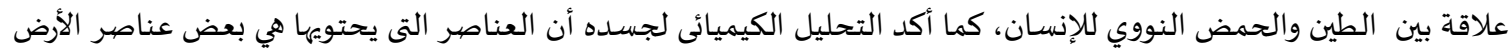
وليست كل عناصرها،(https://ar.wikipedia.org/wiki) وهذا واضح في قوله عز وجل (من سلالة من طين)؛ أي نخبة منها، فالعلاقة قائمة بين الإنسان بالأرض.( سورة المؤمنون، آية 12) 
الدلالة اللغوية للمكان:

وقد ارتبط تعريف المكان في المعاجم اللغوية بالواقع والوجود المادي، فعند ابن منظور"المكان والمكانة واحد، وهو موضع لكينونة

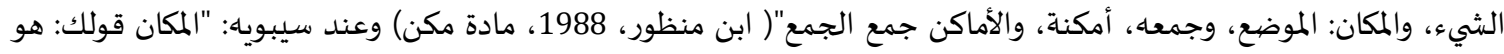

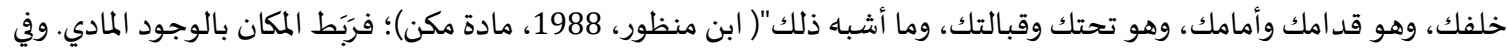
المعجم الوسيط: " المكان: المنزلة، يقال هو رفيع المكان والموضع: جمع أمكنة، والمكانة: المكان بمعنيياء السابقين، وفي التنزيل: "ولو نشاء

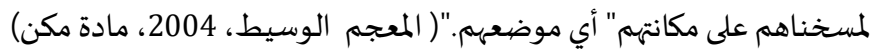

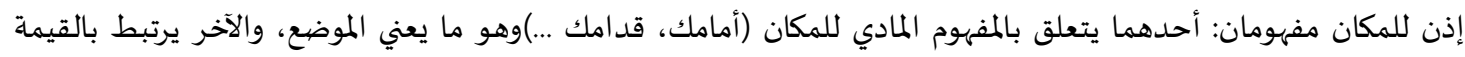

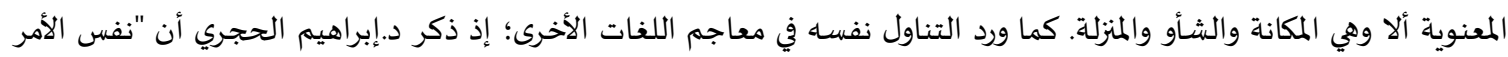
يحدث في الفرنسية؛؛ حيث نجد تنويعات وتسميات مختلفة لهذا المصطلح- المكان -؛ فهناك مثلاً (... Le territoire, le lieu, l'espace, 2011 "le décor, le milieu

الرؤية الفلسفية للمكان:

وقد اتسمت الرؤية الفلسفية لمصطلح المكان بالتصيور المادي نفسه سواء على مستوى الفلسفات الغربية أو عند الفلاسفة

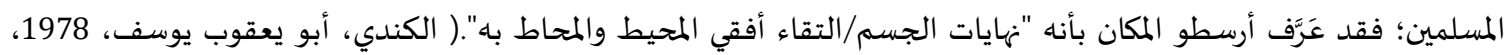

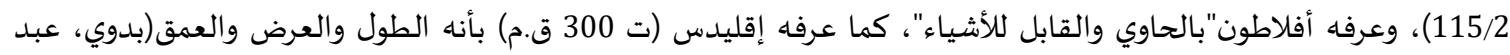
الرحمن، 1975 ) ، كما اتفق تعريف الفلاسفة المسلمين للمكان مع ما ذكره الغرب، فجاء عنهم المكان هو:"السطح الباطن للجسم بهم

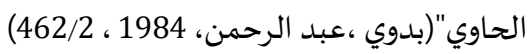
وقد تعززت العناية بالمكان في التصور الفلسفي الغربي الحديث، كما طرقت زوايا أخرى جديدة تصدرها الالتفات إلى العلاقة

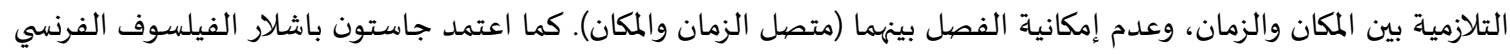

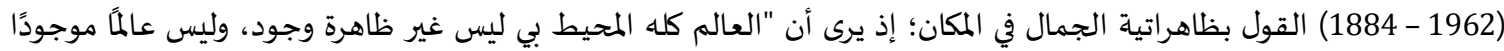

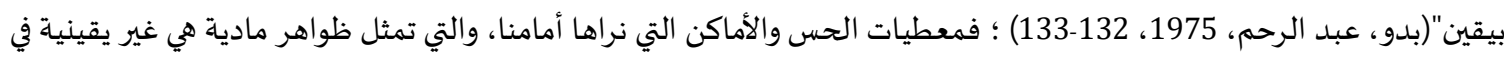

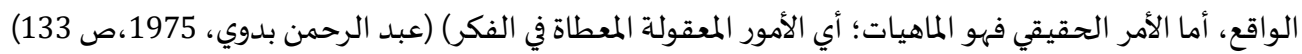

الرؤية الفنية للمكان:

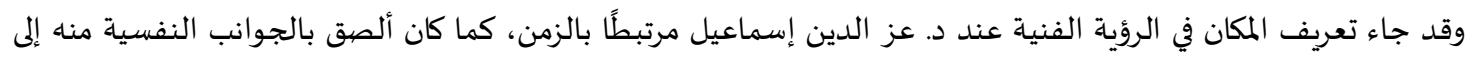

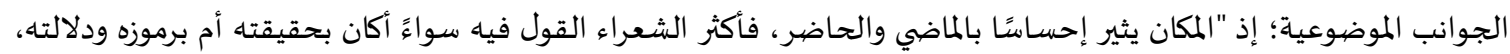

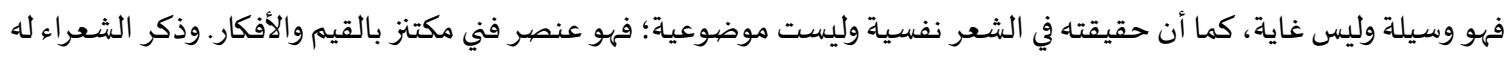

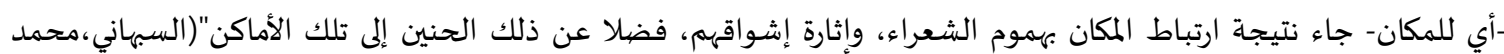

عبيد، 2013، 2013 ويعكس المكان الخلفيات الاجتماعية والسياسية والدينية من خلال تناول الشاعر لما يدور في نفساه، وتناوله لقضاياه؛ إذ (يحوي التجسيد المكاني دلالات اجتماعية ودينية وسياسية، ملتصقة بذات المكان الشاعر، ومعبرة عن مجتمعاه وفكره الحضري والتهية والثقافي، ومن هنا

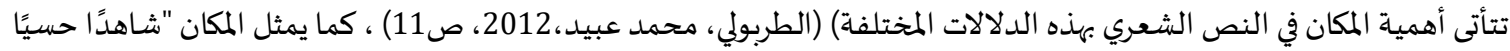

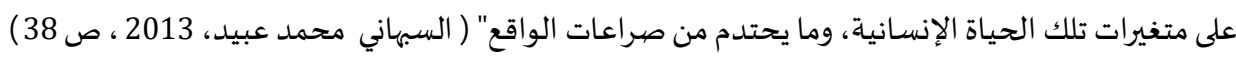

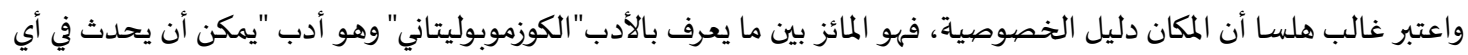
مكان في العالم، ولأي إنسان عدا مكانك وشخصك كانب كقاريء) (باشلار، 1987) وبين الأدب العالمي المعبر عن الملامح القومية البارزة

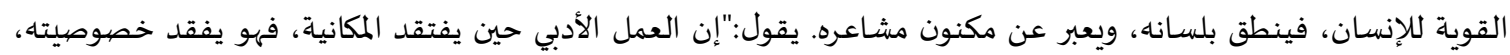

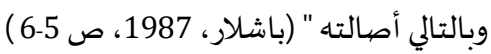
والحقيقة أن للمكان هيمنته وفاعليته، وما من شاعر أنتج ما أنتج إلا في إطار مكاني أثر فياه وتأثر بها، وما تفكيره المستقبلي إلا في إطاره، وما تعديل سلوكاه إلا من انبعاثاته وتوابعه. 


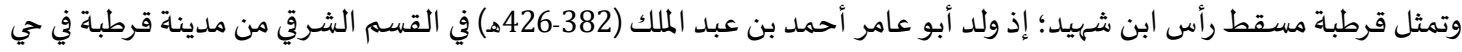

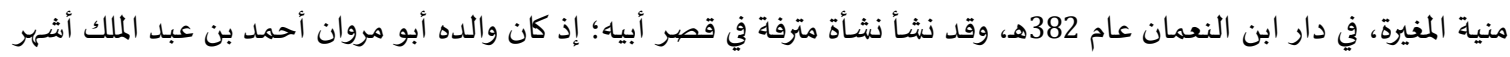

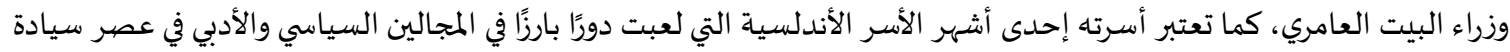

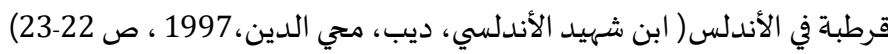

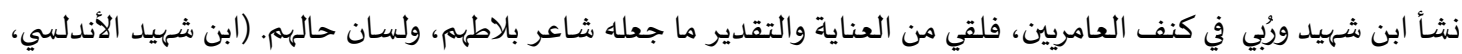

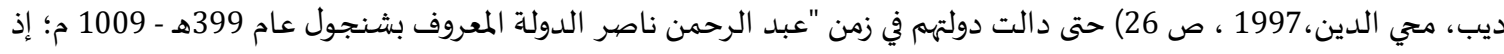

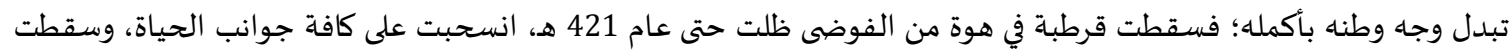

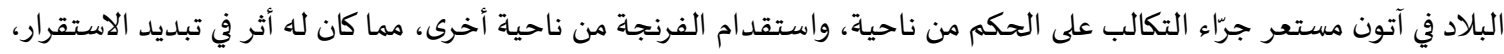

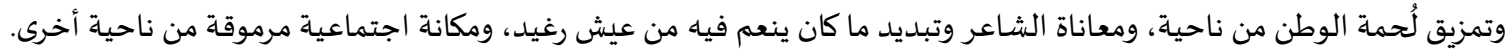

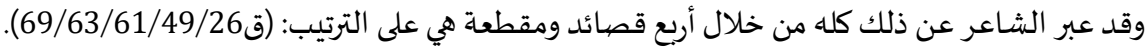

أنساق المكان في شعر ابن شهيد:

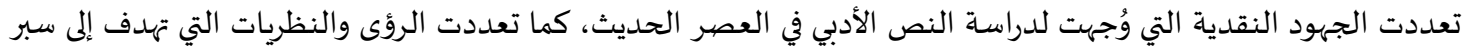

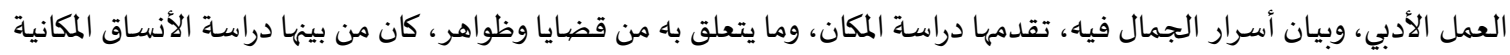

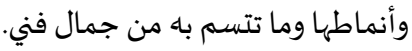
وقد اختلف النقاد اختلافًا كبيرًا في تحديد أنسقة المكان، كما تشعبت بهم الرؤى؛ فقسمت كحلوش أنماط الأمكنة إلى (طباعي/

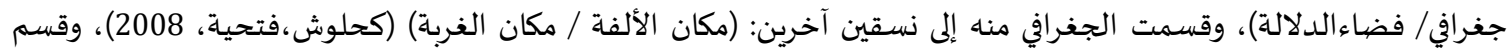

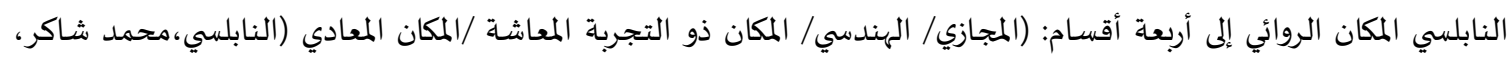

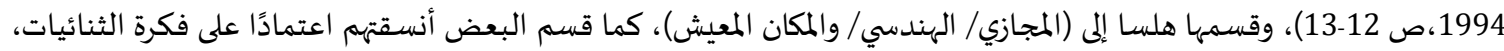

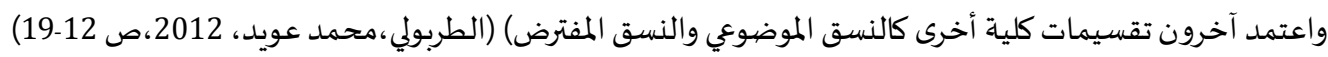
وقد أظهرت التقسيمات المختلفة التي عمد إلهيها النقاد مايلي: 1. 2. كثرة المصطلحات وتشعبها. 3. تعدد العوامل والمؤثرات التي تحكمت في تصنيف الأنساق المكانية؛ إذ منها ما ارتبط بالجنس الأدبي (قرآن/ شعر / قصية/ رواية)،

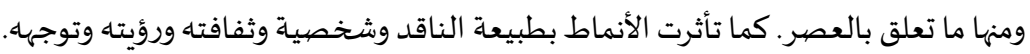

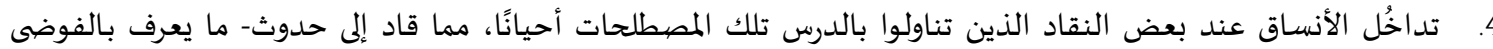

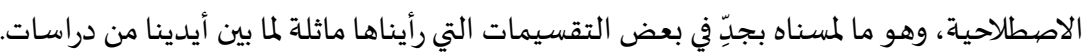

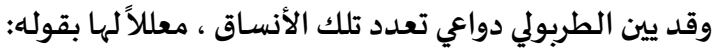

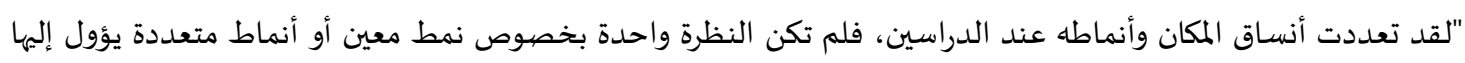

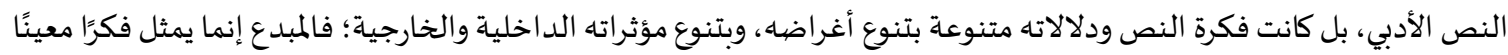

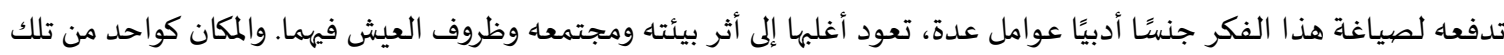

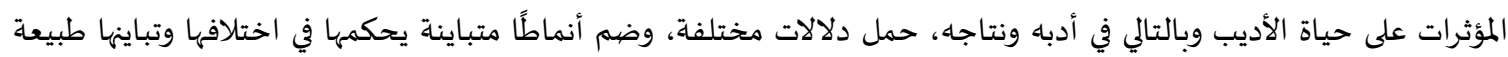

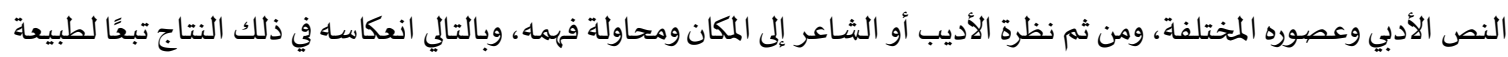

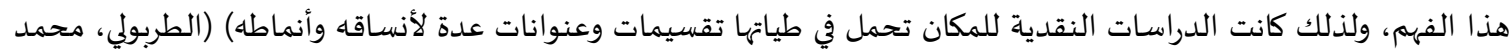

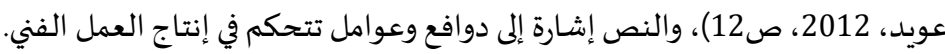

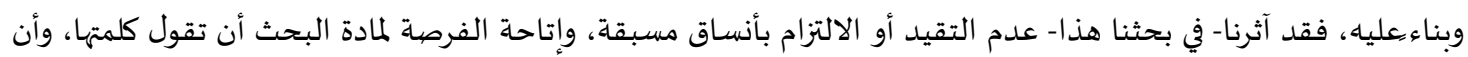

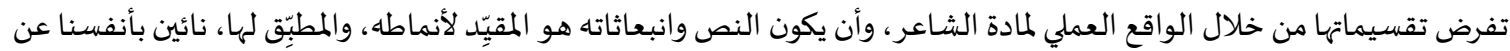

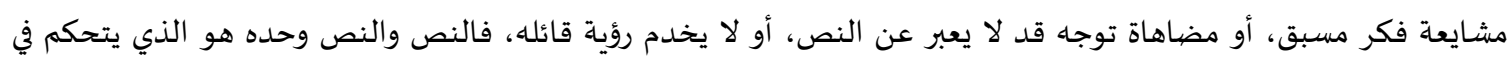
التقعيد للعمل الأدبي. 
أولاً: قرطبة: الحاضبر / الماضي:

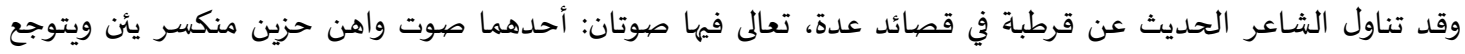

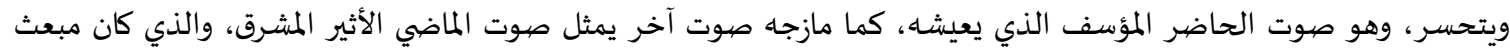

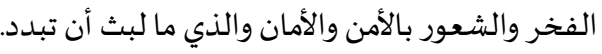

1

ضباع وتشرد:

وقد كان حاضر الشاعر -في تلك الأونة - مؤسفًا، وأنينه لا ينقطع، جرَّاء ما تعرضت له قرطبة من فتن، وما طالها من تدمير، ومن هنا، طالعنا الشاعر بوقفة طللية، تلك التي اعتاد الشعراء الوقوف بها حين يبكون حبيية رحلت، أوأيامًا دالت، أو عاطفة ومأً غيبها

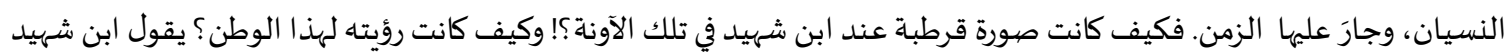

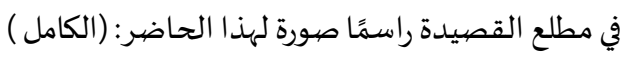

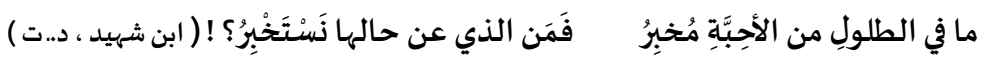
فالشـاعر يستهل القصيدة بمطلع يفيض حزنًا وأسى على ما أصاب تلك البلدة من خراب وتدمير، وما عراها من ضياع وتبديد؛ إذ

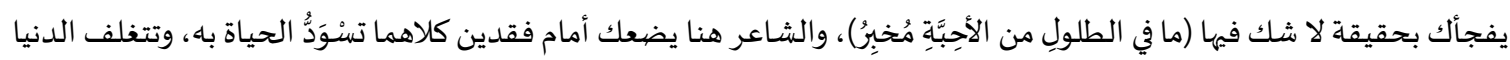

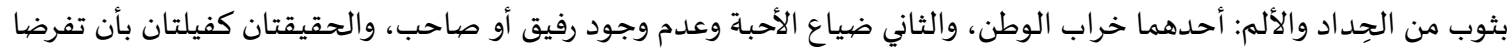

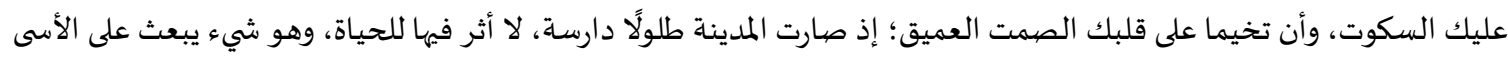

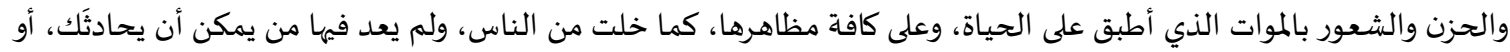

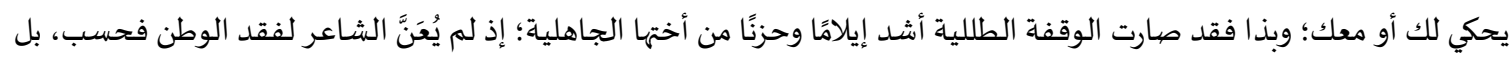

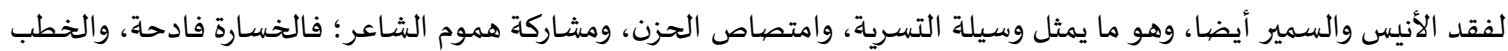

ولا يطيل الشاعر الوقفة التأملية الطللية الخاصة به، ولا يديم التأمل والتفكير في الواقع الماثل؛ إذ يقدم لنا الشاعر - في البيت

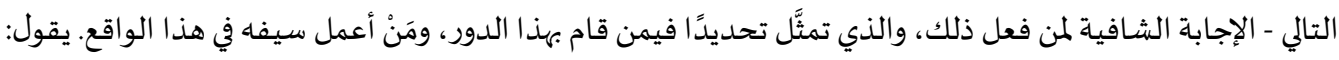

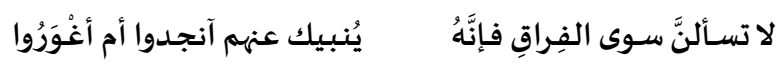

فالفراق هو المِعْوَل الذي هدم قرطبة، وهو الذي صاغ لها هذا المصير، وهو الذي - بلمساته السحرية - مس كافة الكائنات؛ فبدد

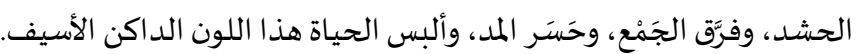

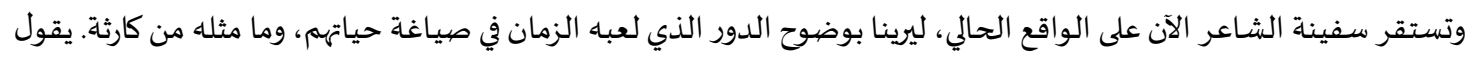
الشاعر:

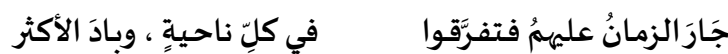

إذ "جار الزمان"، والجَوْر هو الظلم والطغيان، والاعتداء على حقوق الغير، وقد اعتدي الزمان على حقوق قرطبة في الأمن، وسطاً

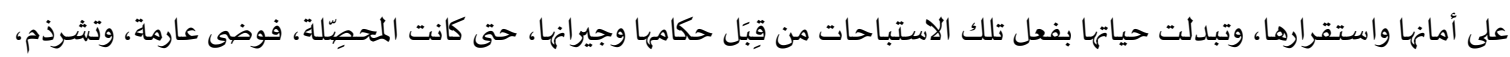

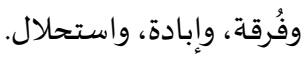
ويكرر الشاعر الحديث عن الأرض والإنسان في متوالية دائمة؛؛ إذ يقول: وفران:

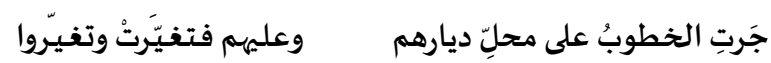

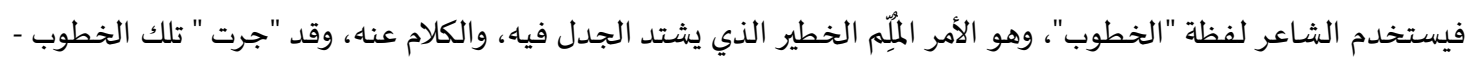

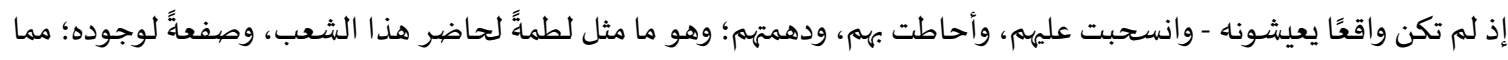

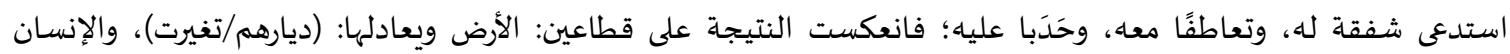
ويعادله:(عليهم/تغيروا ). ويخوض الشـاعر في بعض التفاصيل التي اعترت الحياة السياسية آنذاك، والتي رسمت معالم الحياة في ذلك الوقت، والذي تمثل في انقسام الناس وتحزبهم إلى جماعات، وتفرقهم إلى شيع متنافرين متناحرين، ومن ثم تفرقهم الذي أودي بالحياة فيها. يقول:

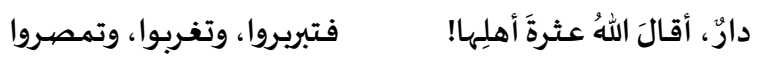




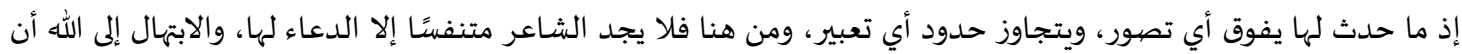

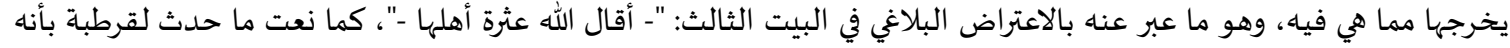

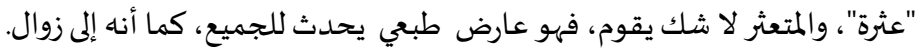

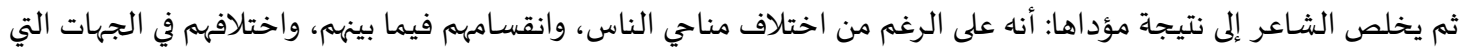
انتهوا إلهها، فقد آلوا إلى نتيجة واحدة. ألا وهي حتمية الفراق:

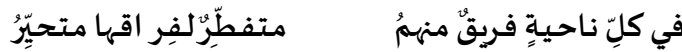

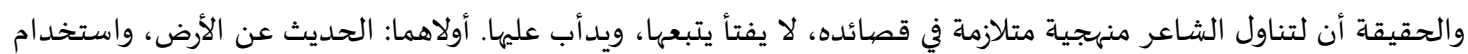

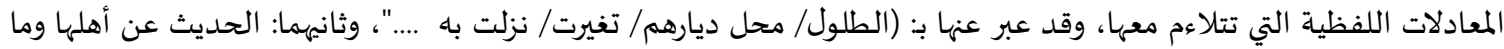

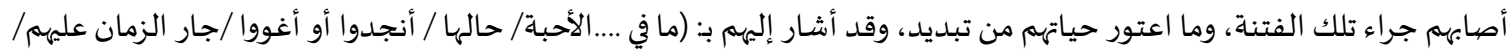

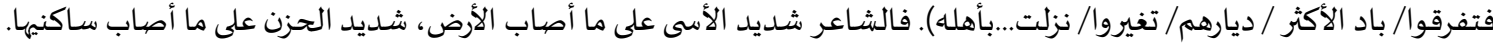

وإذا كان الانقسام آفة شملت حياة الناس، ومضرة لحقت بهم، فقد استفحل الخطب إلى حد إبادة الإنسان، وقتله، وهوما مثل

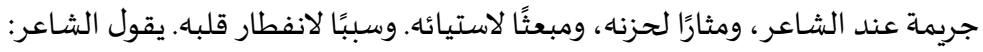

\begin{tabular}{|c|c|}
\hline وِثقاتِـها وحُمَا & ملى سَرَوَاتها ورُو اتِها \\
\hline & على آلآيَهِا وصَفَائهِا \\
\hline يُها ظُرفرائهِها تتفة & للى عُلمَمَائها حُلمَائهِها \\
\hline
\end{tabular}

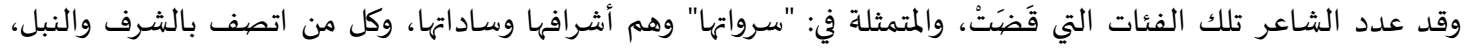

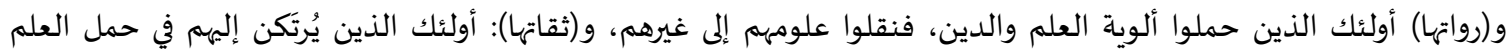

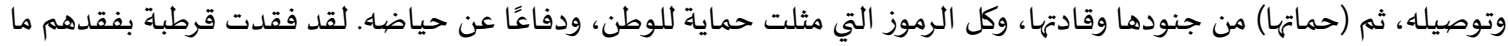

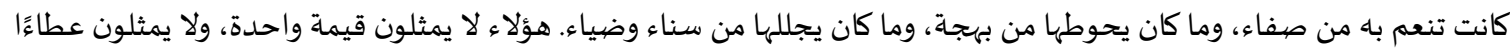

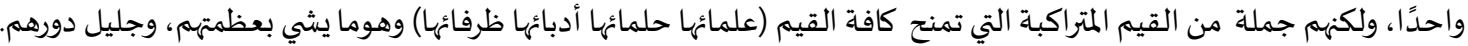

وإزاء ما لقيت قرطبة، وما لقي الشاعر - بالتبعية - من أهوال؛ فقد حثُّ الشاعر يحيى المعتلي - المقيم في مالقة- على دخول قرطبة،

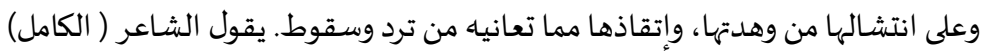

$$
\begin{aligned}
& \text { وعصيـابةً لم تههمْ إشــفاقَها } \\
& \text { الله في أرضٍ غُذِذِيََ هواءَها }
\end{aligned}
$$

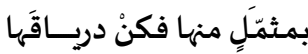

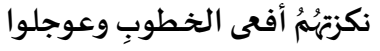

$$
\begin{aligned}
& \text { لوحاولتُ سـوقَ الثريا ساقَها ( ابن شهيد ـ د.ت دئ }
\end{aligned}
$$

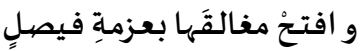

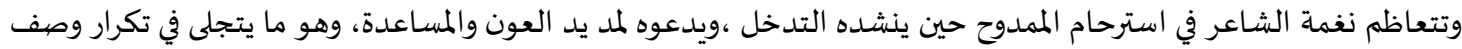

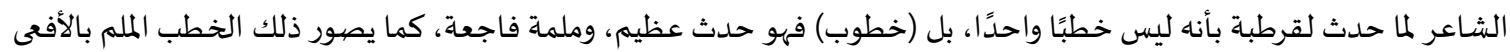

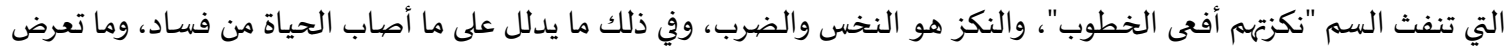

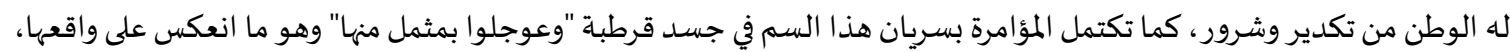
وبدد حياتها. ومن هنا كانت الدعوة "فكن درياقها"، كما كان العلاج "وافتح مغالقها ...".

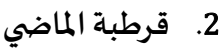

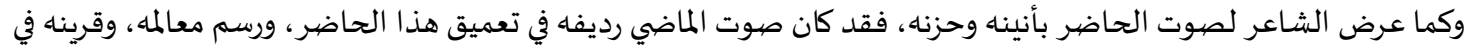

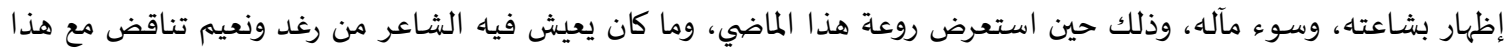

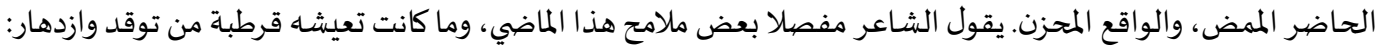

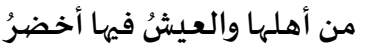

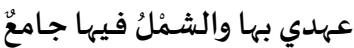

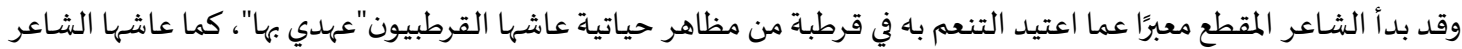

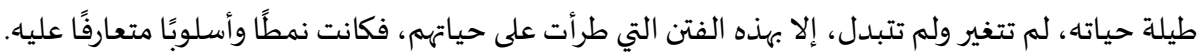




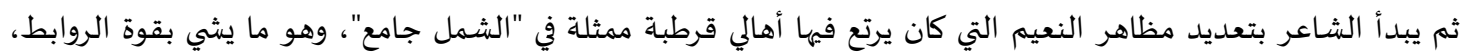

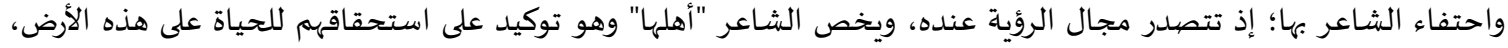

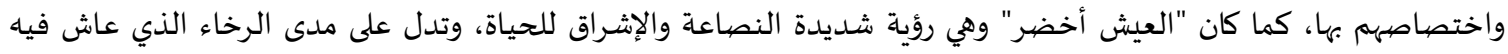

كما سادت أفضيتهم أجواءً عنبرية:

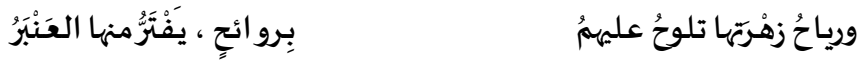

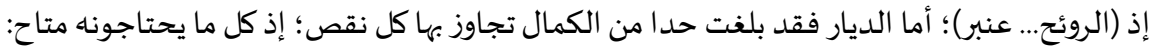

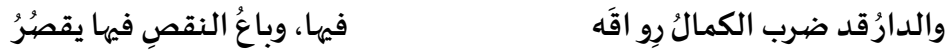

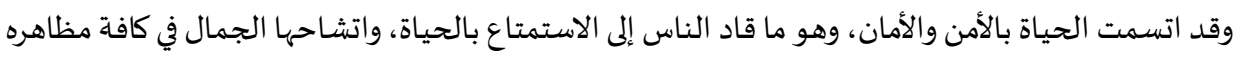

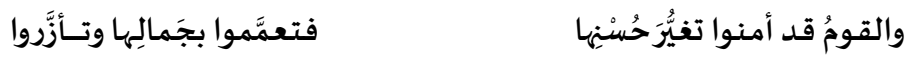

ثم يفيِّل الشاعر في ذكر مظاهر كانت محط أنظار الناس، ورموز حياتهم، وقد تمثلت في القصور والخدور والبيوت، يقول

الشـاعر:

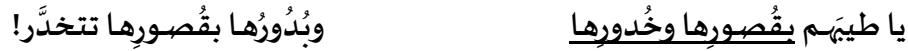

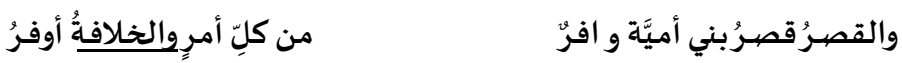

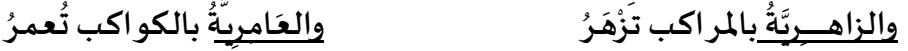

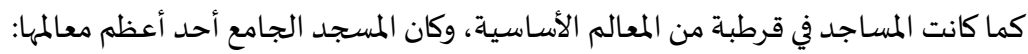

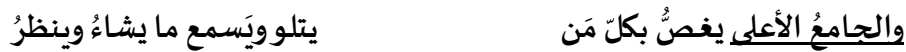

$$
\begin{aligned}
& \text { أما عن الأسواق فقد كانت حاشدة بالناس، آهلة بأهلها: }
\end{aligned}
$$

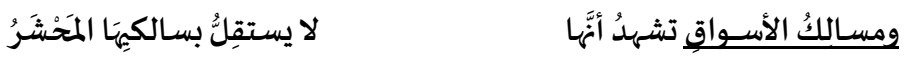

كما كانت قرطبة مصدرًا للأمن، ودرعًا للحماية، وكأهها في قداستها مكانة:

$$
\text { كانت عِراصُُك للميمِّمِ مكَّةً }
$$

$$
\begin{aligned}
& \text { ونعمت قرطبة بطبيعة ساحرة، وكأن أههار الدنيا كلها قد أمدتها بسر الحياة: }
\end{aligned}
$$

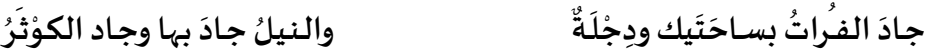

$$
\begin{aligned}
& \text { وسُقيتَ من ماءِ الحياة غمامةً }
\end{aligned}
$$

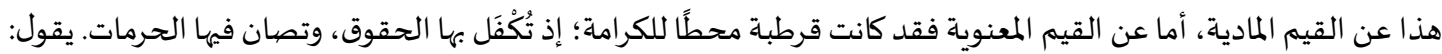

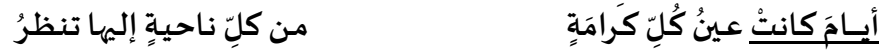

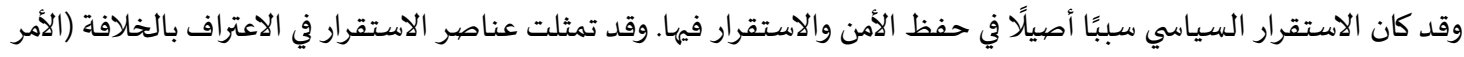

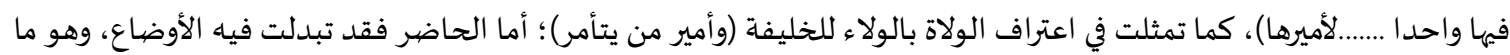

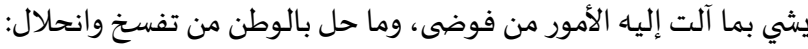

$$
\begin{aligned}
& \text { أياََكانَ الأمرُفيها واحدًاً }
\end{aligned}
$$

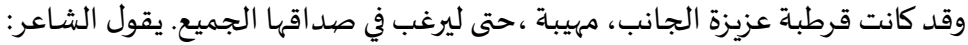

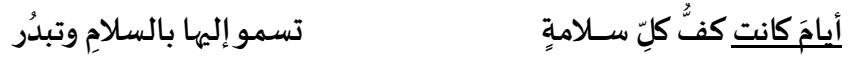

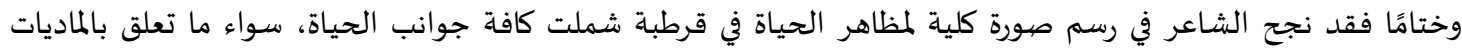

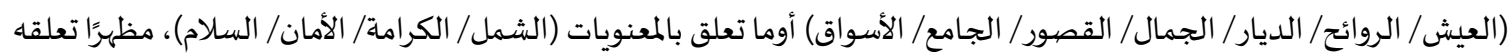

$$
\text { ثقرطبة، وألمه لما آلت إليه الأمور فيها. }
$$

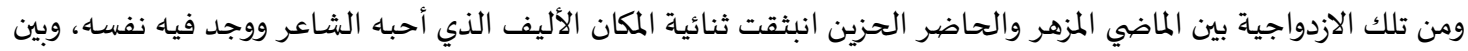

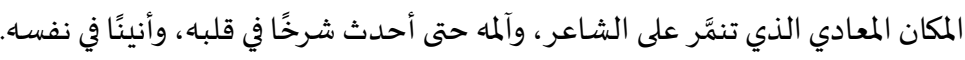




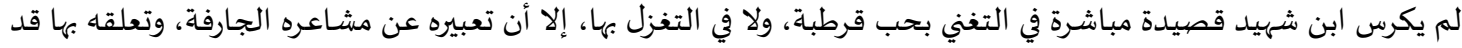

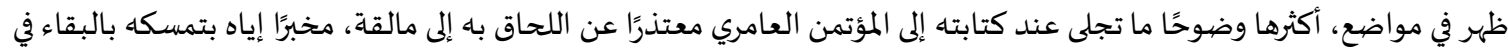

$$
\begin{aligned}
& \text { لها في الحشا صهورةُ الغانيه } \\
& \text { فيـا حبذا هي مِنْ زانيه } \\
& \text { تُدَارُكمـا دارتِ السـانيه }
\end{aligned}
$$

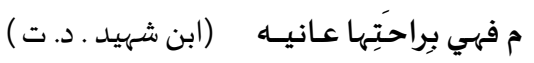

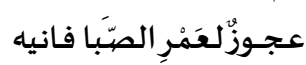

$$
\begin{aligned}
& \text { زنت بالرجـالِ على سنِّهِا }
\end{aligned}
$$

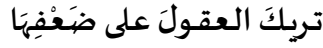

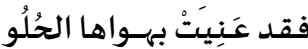$$
\text { والنص يشي بتعلق الشاعر بوطنه، وعشقه له، وتمسكاه بالبقاء فيه، حتى لو كان على هذا النحو المئه المؤلم. }
$$

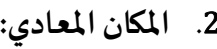

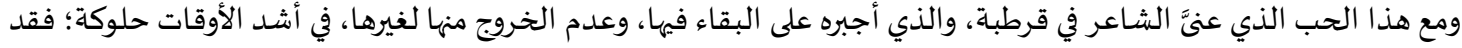

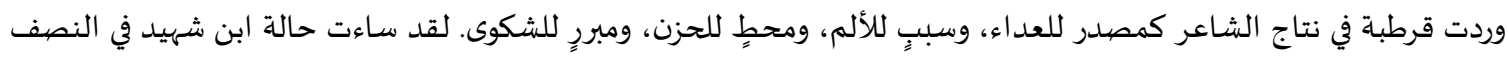

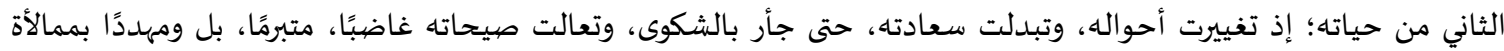

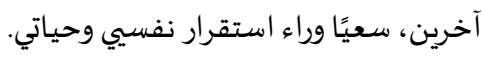

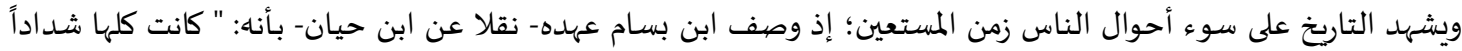

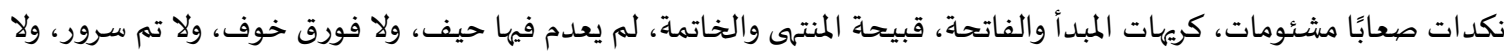

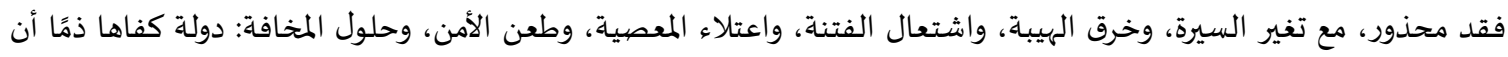

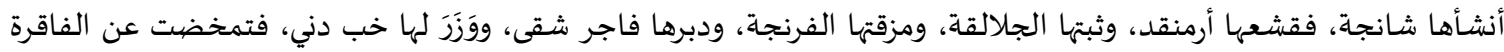

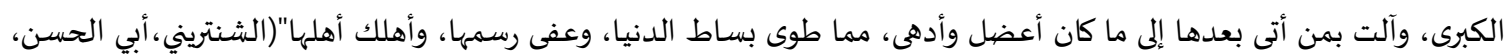

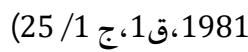

وقد انعكست تلك الفترة على الشاعر، كما تبدت من خلال قصيائده.

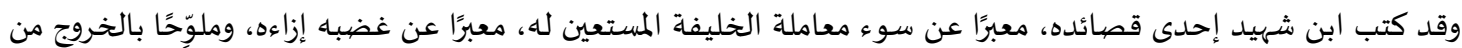

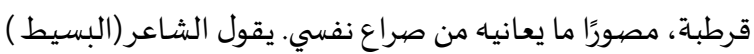

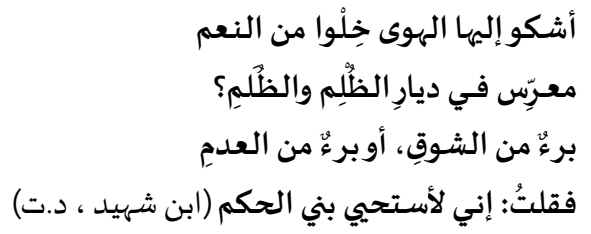

$$
\begin{aligned}
& \text { وقالت النفسُ لما أن خلوت بها }
\end{aligned}
$$

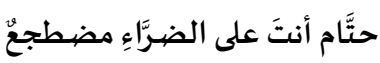

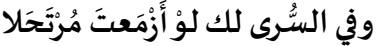

$$
\begin{aligned}
& \text { ثم استمرتُ بفضِلِ القولِ تُنِِْيُني }
\end{aligned}
$$

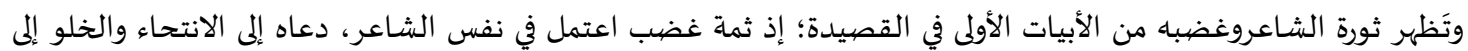

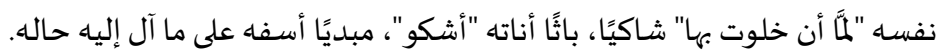

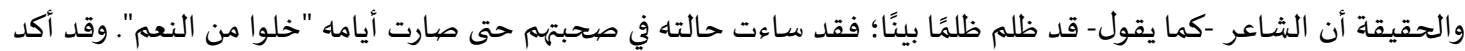

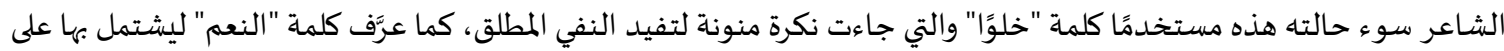

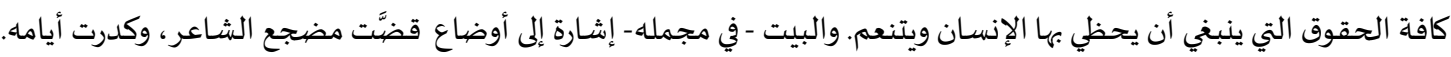

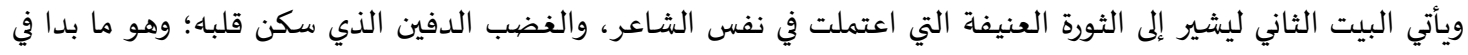

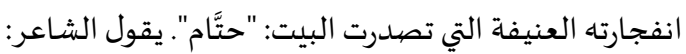

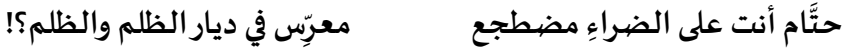

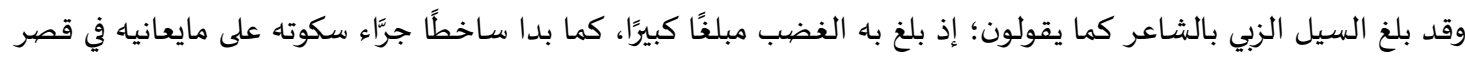

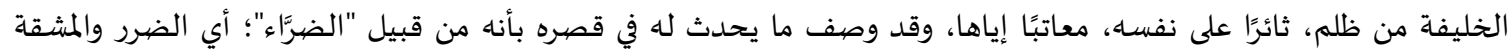
والشدة، كما وصفه بأنه ضرر دائم لا ينتهي "مضطجع/ معرس" التهائ والاضطجاعة هي وضع الجنب على الأرض، والاستلقاء علهيها، فكأهنا

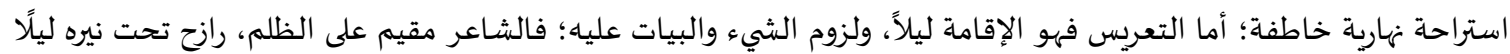

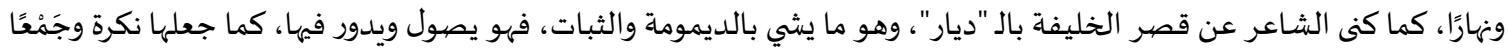


لتدل على اتسـاع رقعة هذا الظلم وامتداده، ووصَفف ما يلاقيه في قصر الخليفة من ظلم بأنه "ظلمات"، وهو استدعاء ديني، له وقعه وإيجاعه.

وهنا يرى الشاعر أن معاناته تلك ليس لها ما يبررها؛ إذ بإمكانه البراءة منها لو هجر قصر المستعين، واتجها إلى من بيده شفاءه. يقول الشـاعر:

$$
\text { وفي السَرَى لك لو أزمعتَّ مُرتَحلا }
$$

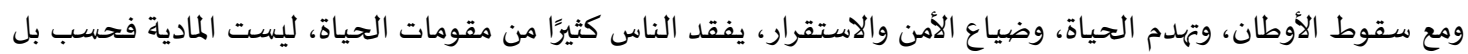

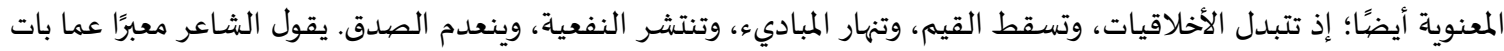

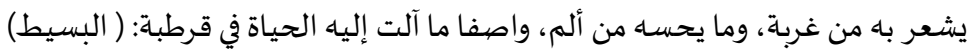

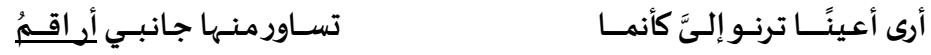

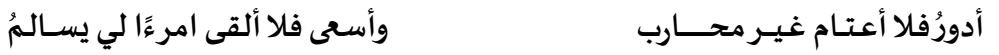

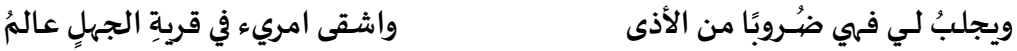

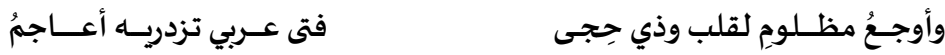

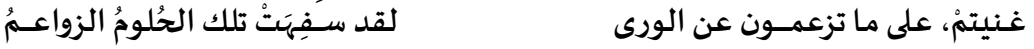

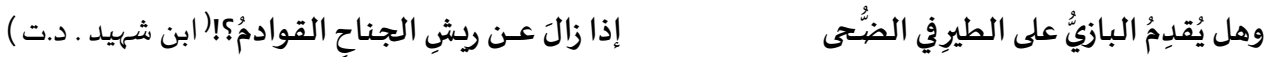

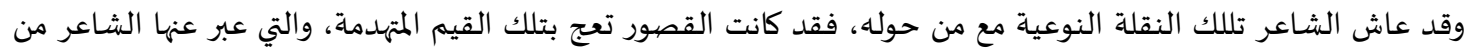

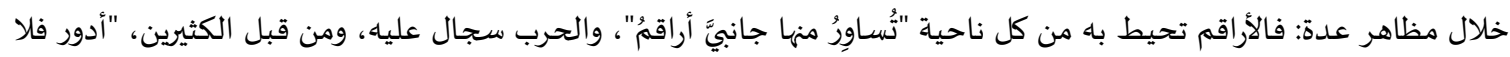

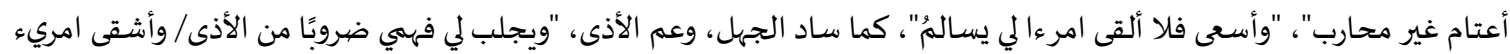

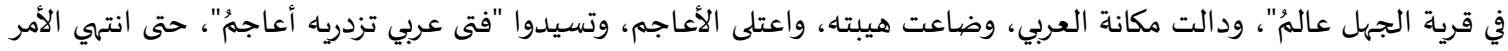

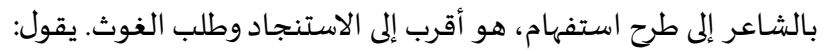

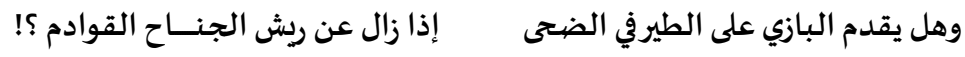

الخيال وأدو اته:

الخيال هو الإطار الخارجي الذي يُقَّم العمل الفني من خلاله، وهو المغلّف له، وموجهه، وصانع تفاصيله ودقائقه، وما المادة

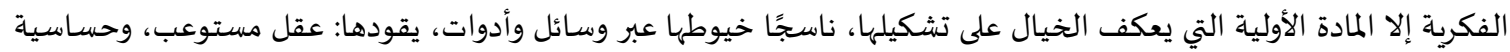

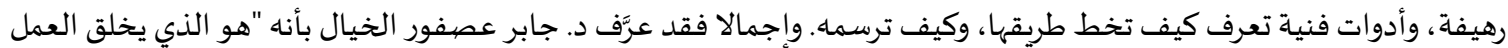

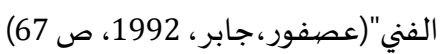
وللخيال دور في معالجة الصورة المكانية داخل العمل الأدبي؛ ذلك أن الشاعر ليس معنيًا بما خطه الواقع من تفاصيل وملامح للأماكن والأبنية، ولكنها يعيد صياغة هذا الواقع بما يتراءى له، وبما يخدم تجربته وسياقه النفسي والفكري؛ فالمكان في العمل الفني

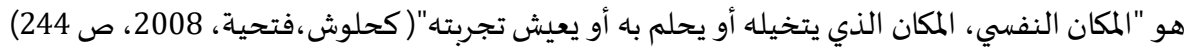
والمكان في العمل الأدبي هو شيء ذاتي، دور الخيال فيه هو إحالة الموضوع إلى ذات، والعام إلى خاص، والكل إلى جزء، حتى لو

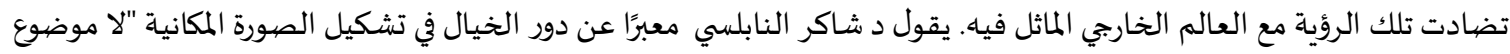
بدون ذات...والخيال هو الذي يصنع تلك الذاتية، وهو الذي يلني موضوعية الظاهرة المكانية -أي كونها ظاهرة هندسية- ويحل مكانها

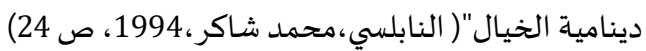
ويقترن دور الخيال بدور الذاكرة في صياغة تلك التجربة، فالذاكرة هي التي تعين الخيال على التمييز، وهي التي تساعده على

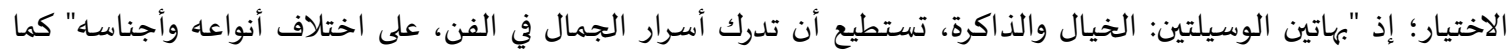

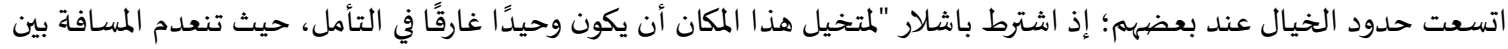

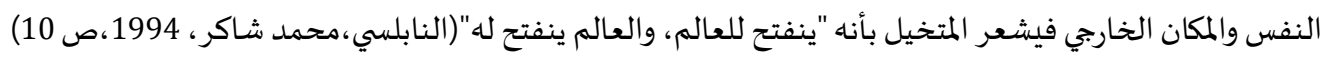

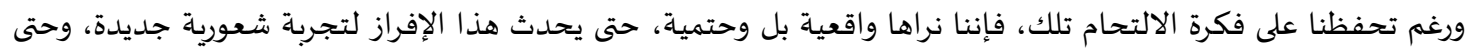
نتمكن من رؤية تجربة متكاملة متوحدة تمثل شعورًا وقضياة، عبَّتر عن نفسها في وضهوح والتحام كاملين؛ فإذا كان الإنسان بعامة

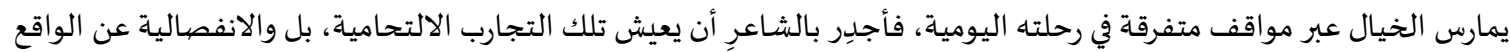
-أحيانًا - حتى يطرح رؤيته، ويفرز صوره، ويرسم مواقفهاه، ويبلور عالمها. 
وللخيال أدواته تلك التي تتجسد من خلاله التجربة الشعرية، وتعبر عن رؤيته وفكره. وقد تميزت الوسائل والأدوات التي توسلها

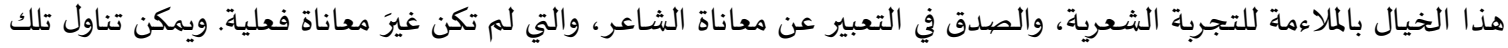

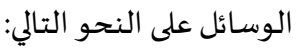

أولاً: الصورة الشعرية

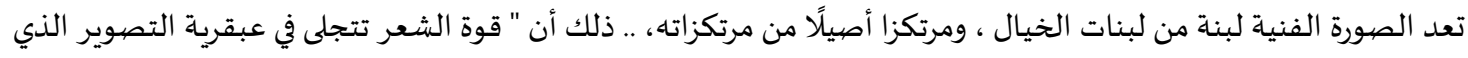

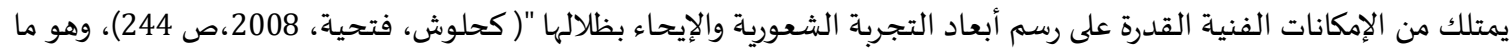
تحقق عند الشاعر عبر قنوات ووسائل عدة.

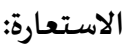

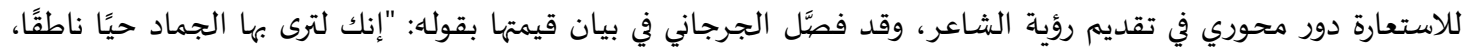

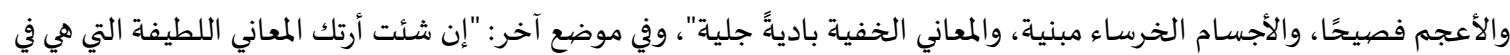

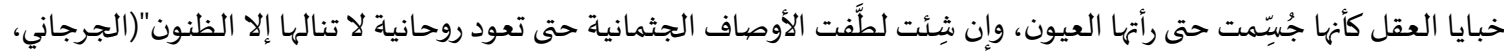

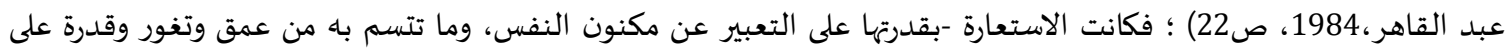

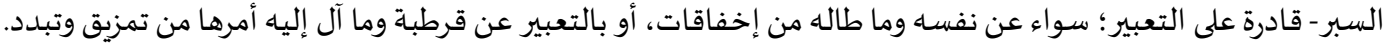

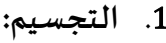
وقد غلبت قيم (الفراق/الزمان/الخطوب) على حديث الشاعر في تلك الآونة، كما تعالت معها أناته وأحزانه تلك التي أعقبت زوال

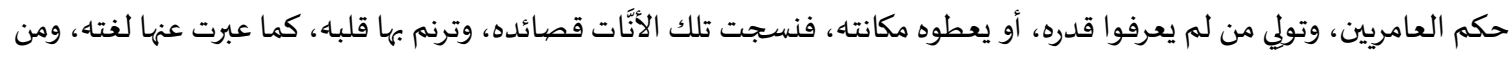

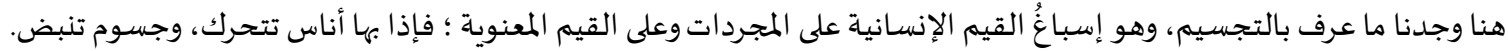

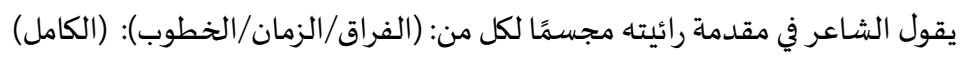

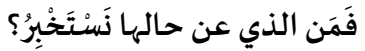

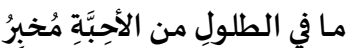

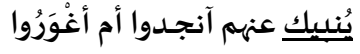

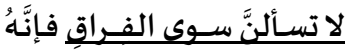

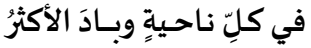

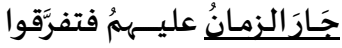

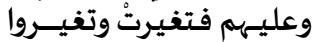
حَرَت الخُطوبُ على مححلِّ ديارهم

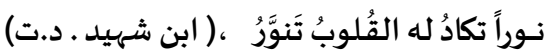

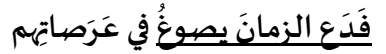

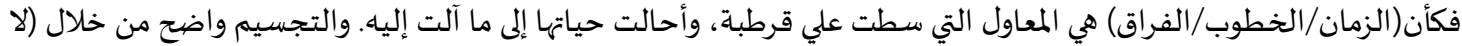

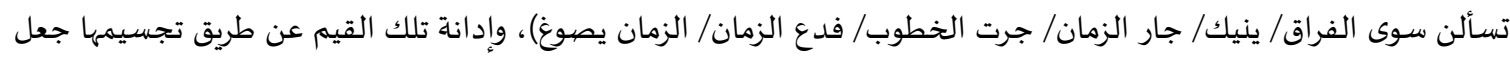

منها أناسا مسؤولة يدينها الشاعر ، ويحملها تبعة فِ فِعالها.

2. 2. 2.

والتشخيص هو أن يسبغ الشاعر أحاسيسه ومشاعره على الأشياء المادية المحيطة؛ فإذا بها شخوص تمشي وتتحرك. وقد مثلت

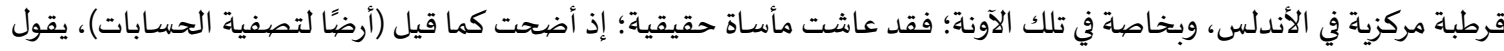

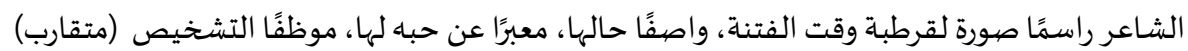

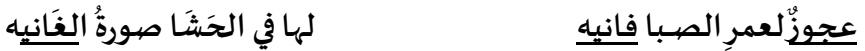

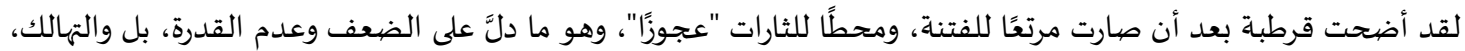

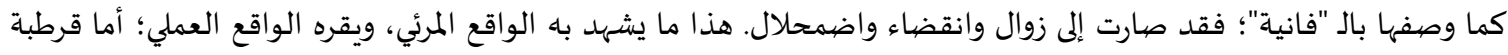

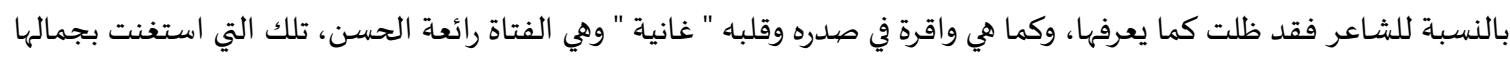
عن الزينة. والمفارقة واضحة بين واقع قرطبة والواقع النفسي للشاعر . ثم يقول:

$$
\text { زنتُّ بالرجالٍ على سنيّها }
$$

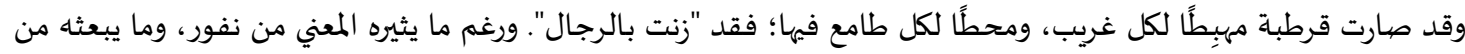

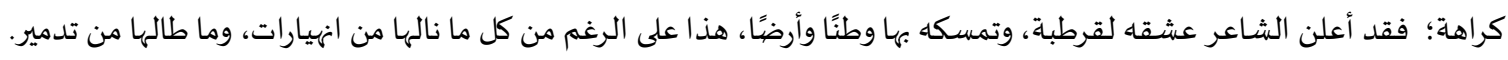

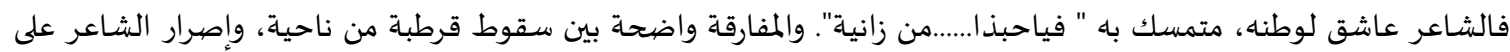

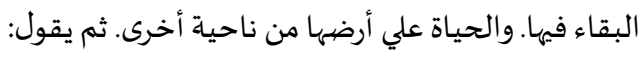

تُدار كما دارتُ السانيه

تُرِكِ العقولِ على ضَعْفهـا 
وهي ورغم ما آلت إليه من ضعفٍ بادٍ إلا أنه يراها قوية، ذات قدرة وتمكن، بل جعلها كالسانية أو كالساقية أو الناعورة التي تجر

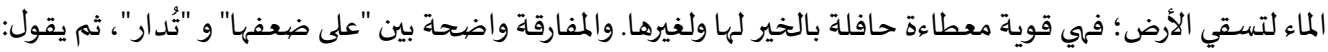

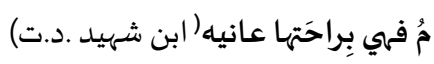

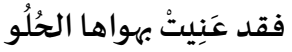

وتشخيص قرطبة في صورة امرأة هي رؤية لوضعيتها؛ فهي أصل للحياة، ومركزية لها.

وقد كنى الشاعر كثيرًا عن الظروف والأوضاع التي عاشها، سواء ما تعلق منها بقرطبة، أوما تعلق بمعاناته هو. والكناية "لفظ أريد

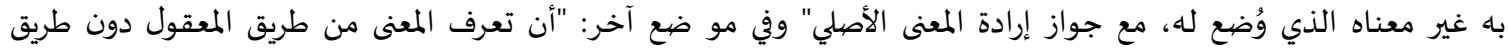

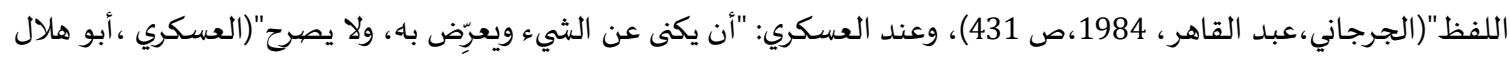

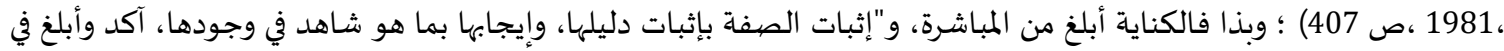

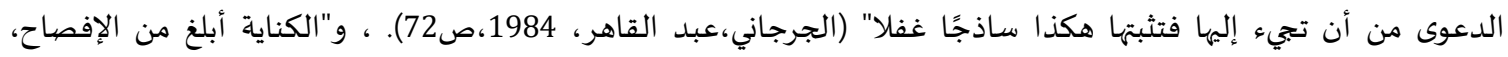

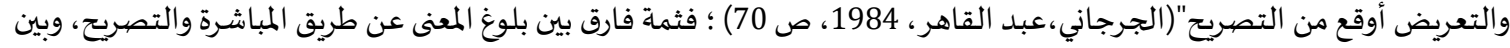

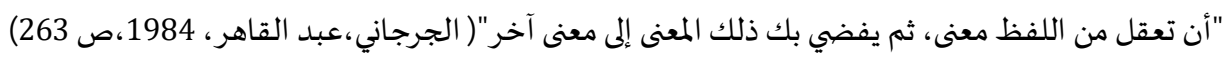

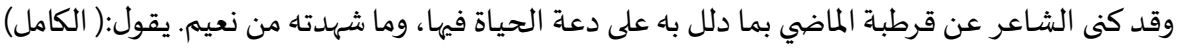

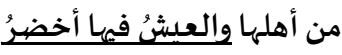

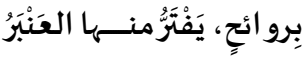

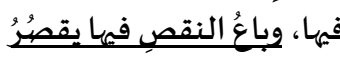

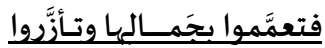

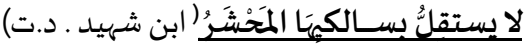

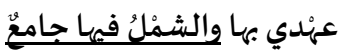

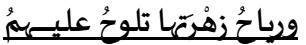

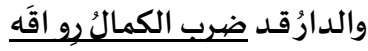

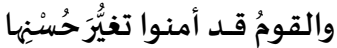

ومسسالِكُ الأسـواقِ تشهندُ أَنَّها

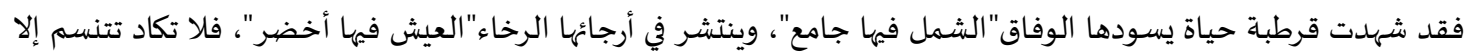

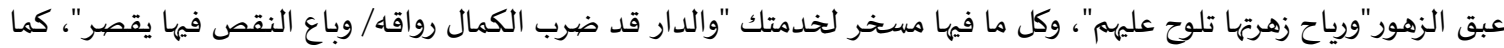

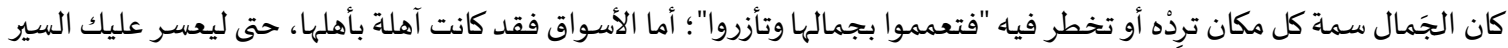
فيها "لا يستقل بسالكيها المحشر" كما وظف الشاعر الكناية للتعبير عن ذاته، وما يعانيه من أرق جرَّاء تلك الأحقاد التي يجابهها في قصر المستعين الأموي، وما يناله

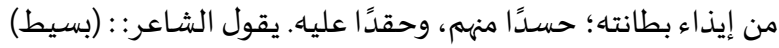

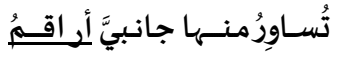

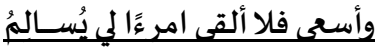

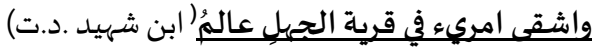

\section{أرى أعينًا تــنـو إلسئَ كأنما}

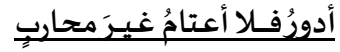

ويجلبُ لي فهي ضُروبًا مِنِ الأذى إنى

فالشاعر لا يرى حوله إلا "أراقم"، وقد اجتمعوا على حربه: "لا أعتام غير محارب"، "لا ألقى امرءًا لي يسالم". وقد كان سبب ذلك فئل

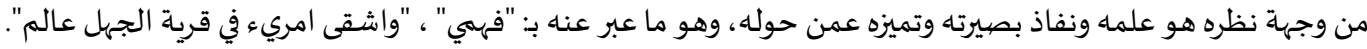

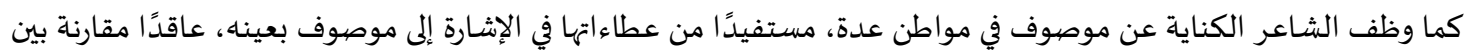

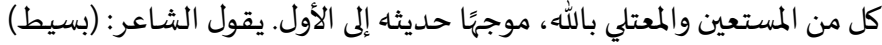

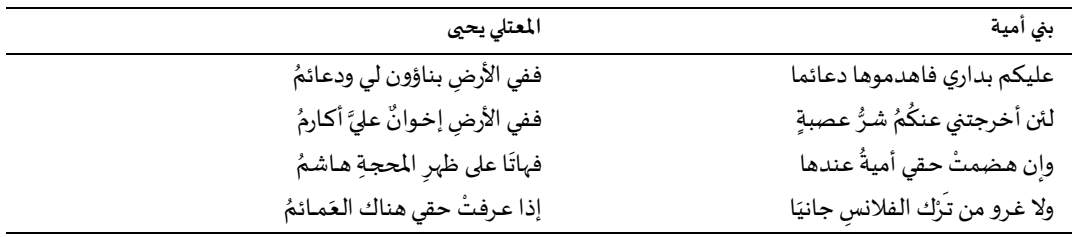

فالشاعر كني عن المستعين في الأشطر الأربعة الأولى من الأبيات، كما كني عن المعتلي مُعينه وساعده وداعمه بالأشطر الثواني من

الأبيات نفسها.

التشبيه:

والتشبيه هو"الوصف بأن أحد الموصوفين ينوب مناب الآخربأداة التشبيه، ناب منابه أو لم ينب"(الجرجاني،عبد القاهر،

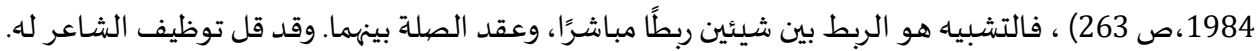




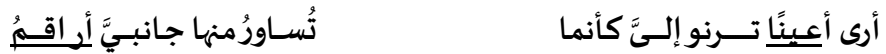

- ومن أمثلته وصف حساده بالأراقم:

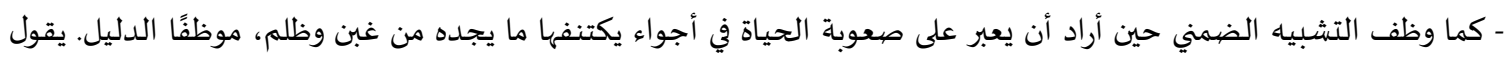

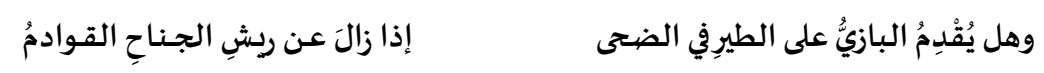

الشاعر:

ثانيًا: المحسنـات البديعية

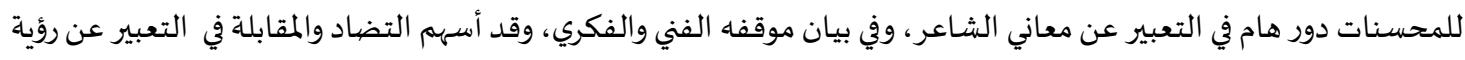

$$
\text { الشاعر ، كما سيتضح على النحو التالي. }
$$

1. 1 التضشاد:

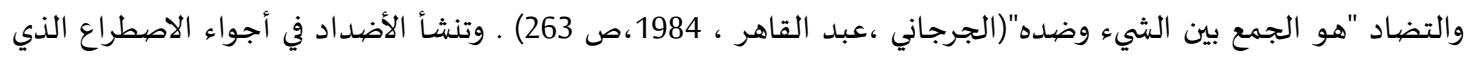

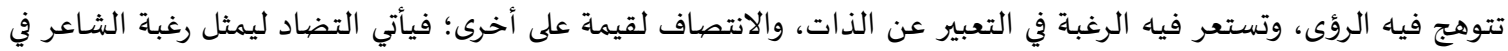

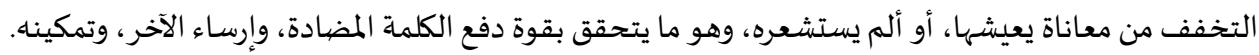

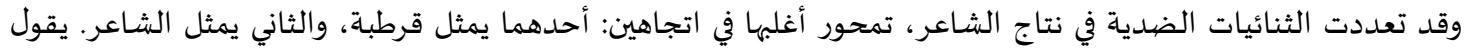

\section{يُنبيك عنهم آنجدوا أُم أغْوَرُوا}

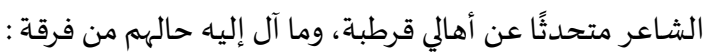

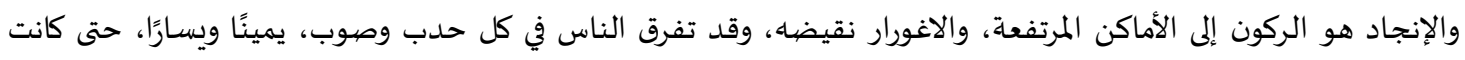

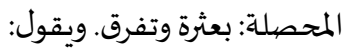

\section{والدارُقد ضربَ الكمالُرو اقَه فهيها، وباعُ النقصِ فيها يقصُرُ}

فقد كانت قرطبة مفخرة عصرها، ومحط أنظار الناس، قاطنيها وزوارها. ويقول:

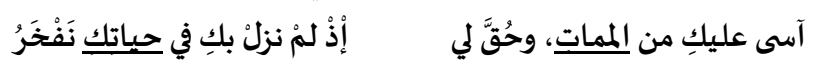

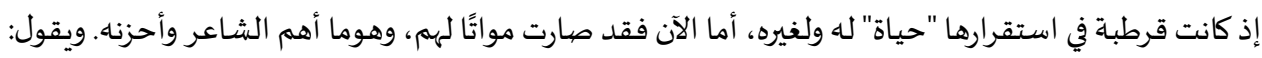

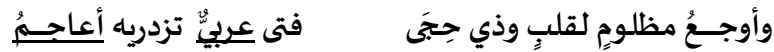

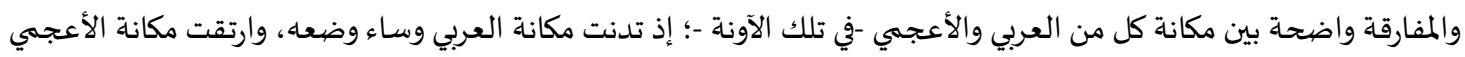

$$
\text { وتسيَّد، وهو ما آلم الشاعر، وأثار استياءه. }
$$

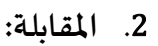

وقد فرض الصراع الدائر بين الشاعر والتحديات المحيطة باه، توظيف المقابلات وهي: "إيراد الكلام ثم مقابلته بمثله في المعنى

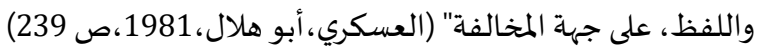

$$
\begin{aligned}
& \text { وقفَ الزمانُ لها هناك فعاقَها } \\
& \text { وإذا ارتمتْ نحسوي المُنَى لأنالَها }
\end{aligned}
$$

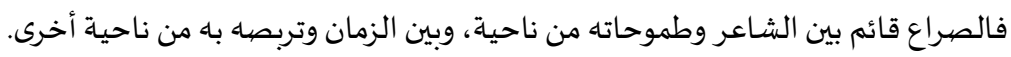

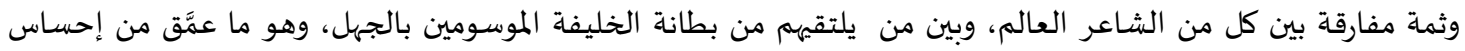

الشاعر بالأسى، وضاعف من إحساسه بالغربة. يقول:

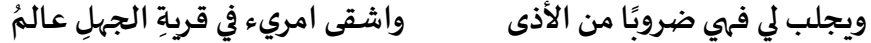

كما تعمق إحساس الشاعر بالغربة، جرًاء ما أصاب الناس من تغير أحوالهم؛ وسيادة النفاق بينهم. يقول:

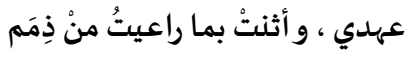
تخونتني رجالَّ طالما شَكَرَتْ ثالثًا: الحواس:

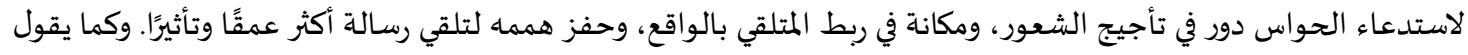

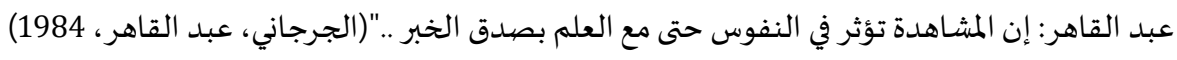


والحق أن توظيف الصورة البصرية عند ابن شهيد كانت أمرًا حتميًا بالنسبة للشاعر، إذ كان لابد للشاعر من رسم صور مادية

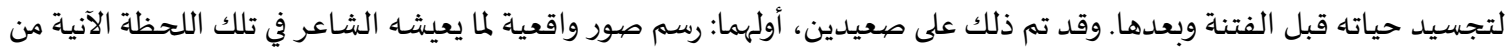

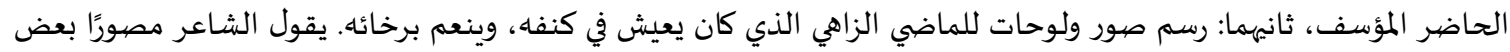

المظاهر الحضارية في قرطبة الماضي:(الكامل)

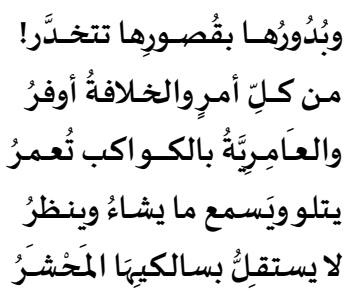

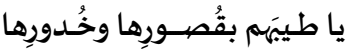

$$
\begin{aligned}
& \text { والقصيسرُقصـرُبني أميَّة و افرُ }
\end{aligned}
$$

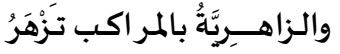

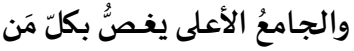

$$
\begin{aligned}
& \text { ومسـالِكُ الأسـواقِ تشـهـدُ أنهَّا }
\end{aligned}
$$

فقرطبة الماضي أزهرت الحياة فها بما نعمت به من (القصور والخدور والبدور الجوامع والأسـواق). وكلها مظاهر للحياة المتدفقة،

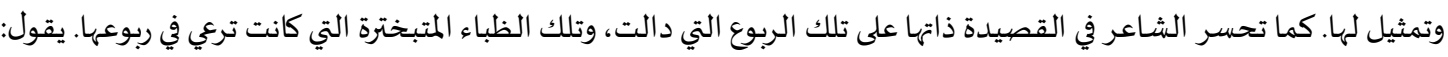

$$
\text { أسـَفى على دارعهـدتُ ربـوعَهـا }
$$

و(الربوع): هي الأراضي الربيعية التي تنعم بالجمال والخضرة، والتبختر هو التمايل والسير على نحو من التؤدة والاسترخاء. فأراضي

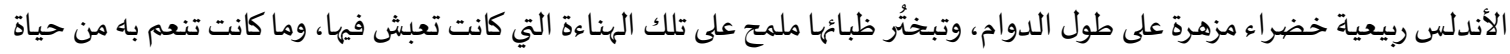

$$
\text { رخية، وأمن وسلام. }
$$

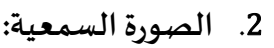

كما غلبت الصهورة السمعية على الصهورة حين استصرخ الشاعر المعتلي، وحثـه على غزو قرطبة، والوقوف إلى جوارها، وانتشالها

$$
\begin{aligned}
& \text { من وهدتها، يقول الشاعر:( الكامل) } \\
& \text { وعصيابةٍ لم تتهـه إشـفاقها }
\end{aligned}
$$

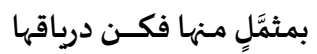

$$
\begin{aligned}
& \text { لوحاولت سـوْقَ الثريا سـاقهيا } \\
& \text { تتعرض الجوزاء حـل نطاقها } \\
& \text { فالصورة السمعية ظاهرة واضحة في: (غذيت/تههم/ نكزتهم/افتح/حاولت/سوق استلها/تتعرض/حل). } \\
& \text { الله في أرض غذيت هــواءها } \\
& \text { نكزتهـ أفعى الخطوب، وعوجلوا } \\
& \text { و افتـــــمغالقها بعزمةِ فيصلٍٍ } \\
& \text { ولكو أنها منه، إذا مـا اسـتلهيا }
\end{aligned}
$$

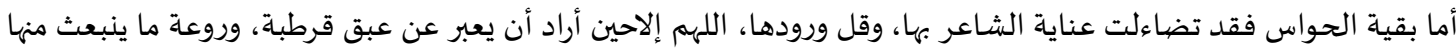

من روائح، كما عرض لحاسة الذوق حين جعل للموت طعمًا.

ويبدو لي أن محاولة حصر الوسائل التي يوظفها الشـاعر في إنتاج صوره ورسم ملامحها إن هي إلا من قبيل الاجتهاد، والسعي لرؤية

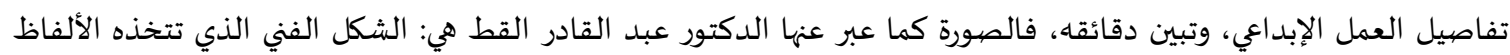
والعبارات بعد أن نظمها الشاعر في سياق الدلالة، والتركيب والإيقاع والحقيقة والمجاز، والترادف والتضاد والتجانس، وغيرها من

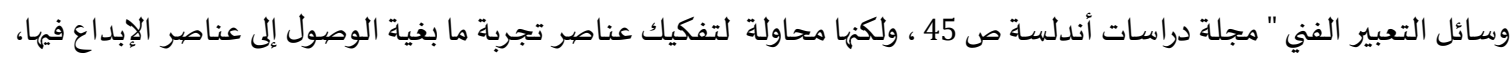
وبيان عناصر عبقرية قائليها.

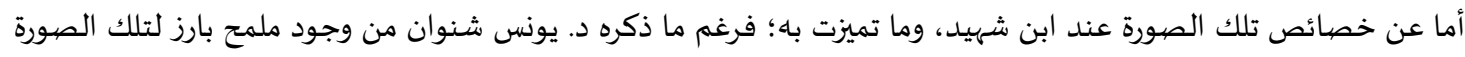
وهوما عبر عناه بأنها " تنسـاب بوضهوح ويسر" ص 35 ، - وهو ما احتاج إليه الشاعر من أجل طرح قضيتها والتعبير عن نفسـاه الملتاعة

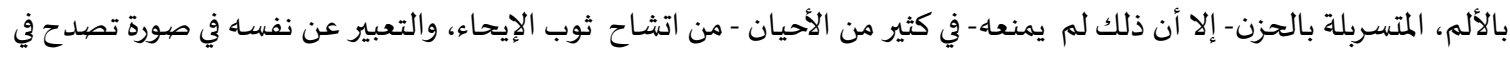

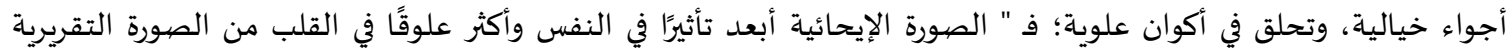

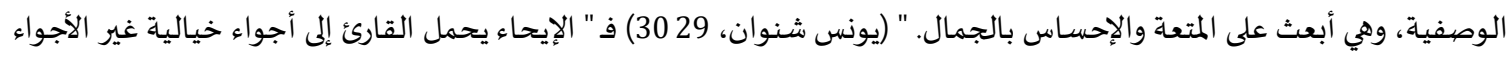

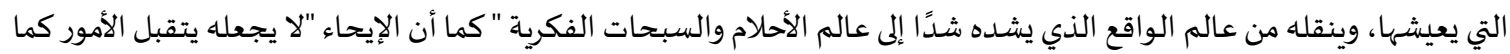

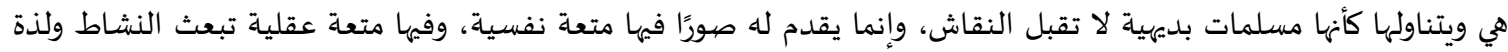

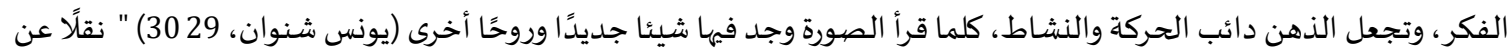
الصورة الشعرية في شعر بشار صدرد 83 
ويكفي أن نراجع مقطوعة الشاعر في عشق قرطبة (عجوز لعمر الصبا فانية) لنرى تلك الآفاق التي حلق فيها الشـاعر حين جعل

من قرطبة امرأة عجوز متهالكة، يزني بها الرجال ، ويحط بها كل معتد، ولكنها بالرغم من ذلك ظل عاشقًا لها، مؤثرًا لها على ما عداها.

رابعًا: اللغة المكانية في شعر ابن شهيد

مثلت اللغة المكانية لابن شهيد جزءًا من الإطار الثفافي للشاعر، والذي تشكل عبر المبر رافدين:

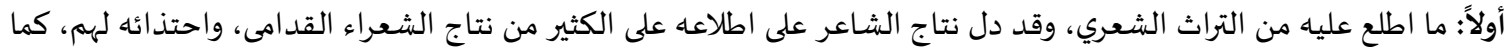

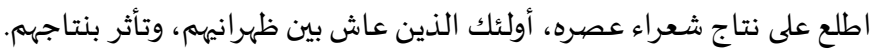

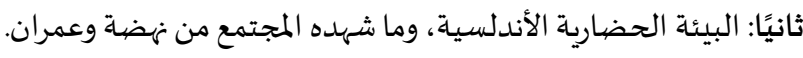

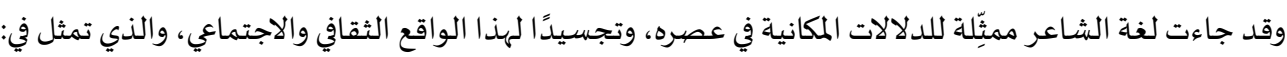

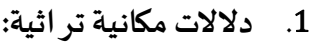

استخدم الشاعر-في إطار ما ندرس- كلمات ذات دلالات مكاتية مكانية تراثية جاءت نتاج قراءات الشـاعر، تمثلت في:

الطلول:

وقد عايش الشـاعر تجربة الوقوف على الأطلال، مثله مثل غيره من الشعراء القدامى، وذلك حين دُمرت قرطبة، وصارت مسرحًا

للخراب، وبادت كافة صور الحياة فهها، ومن هنا وقف الشاعر على أطلالها يبكي ضياعها، وتبدد الأحباب بها. يقول:

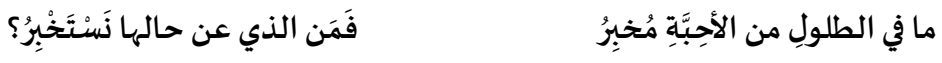

أنجدوا / أغوروا:

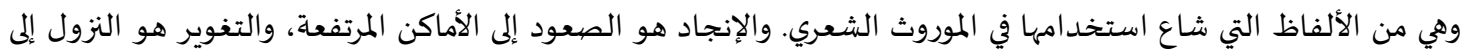

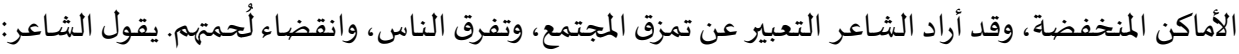

$$
\text { لا تسـألنَّ ســـوى الفِراقِ فإنَّهُ }
$$

العرصيات:

كما استخدم الشاعر كلمة "العرصات"، وهي من المفردات التراثية التي استخدمها الشعراء العرب للتعبير عن مقدمات الديار وأفنيتها، وقد وظفها الشاعر هنا، مع إضفاء مسحة من القد اسة عليها؛ إذ جعل عرصات قرطبة تعادل في قد استها مكة. يقول:

$$
\text { كانت عِراصُُـك للميمِّم مكَّةً }
$$

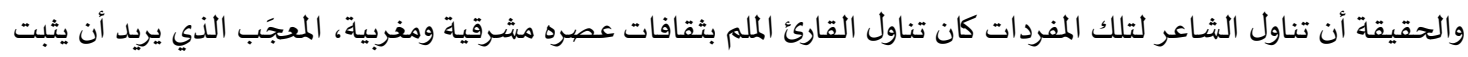
اقتداره وتمكنه وقدرة على التمثل والاحتذاء، المتعصِب لما هو عربي مشرقي، المعتِّمِ لهذا التراث، الشاعر بقيمته. ومن هنا كان

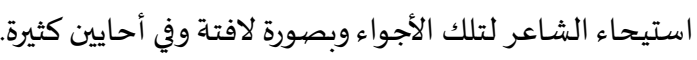

2.

أما عن الألفاظ التي انبثقت عن البيئة الأندلسية، وأفرزها الواقع الحضري، وعبرت عنده؛ فئه فقد تمثلت في ألفاظ:

قرطبة:

وهي البلدة التي عاش فيها الشاعر، نَعِمِ بها في النصف الأول من حياته، كما رثاها في النصف الثاني منه. وقد ذكرها مرة واحدة

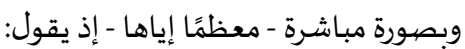

$$
\text { فلمثل قُرْطُبِةٍ يقلُّ بكاءُ مِن }
$$

كما أشار الشاعر إليها مجازًا حين وصفها بالعجوز / الغانية / الزانية:

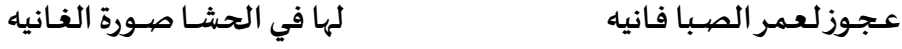

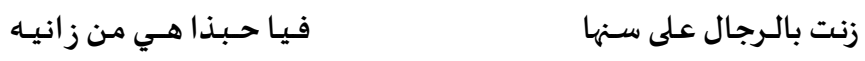$$
\text { وفي تصيوير انسداد الأفق، واستشراء الخراب بها، يصف الشـاعر قرطبة بأهها "مغالق": }
$$

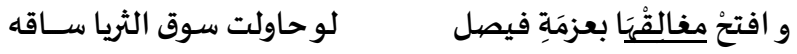

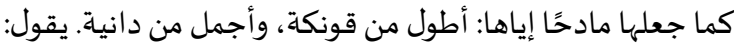

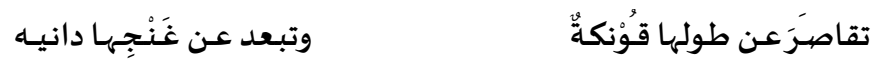


وقد كثر ذكر كلمة القصور عنده، استجابة للواقع الذي عاشه، فهي إحدى المفردات الحضيارية المعبرة عن البيئة الأندلسية.

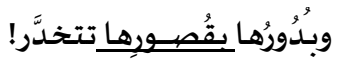

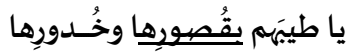

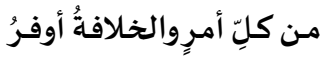

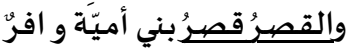

$$
\begin{aligned}
& \text { والعَامِيسِّةُ بالكو اكب تُعـمرُ } \\
& \text { كما خص قصورًا بعينها مثل قصر الزاهرية. يقول: } \\
& \text { وكنى عن مقر العلويين بقصر سهيل، منددًا بالمستعين، مشيدًا بمناصرة العلويين له. يقول الشـاعر: }
\end{aligned}
$$

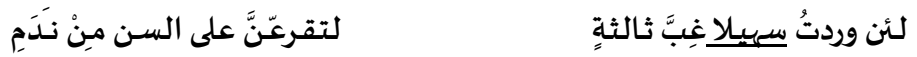

$$
\begin{aligned}
& \text { المسساجد: } \\
& \text { ومن المعالم الشهيرة في قرطبة المسجد الجامع. وقد كان ملتقيً للعلم دينًا ودنيا. يقول: } \\
& \text { يتلوويسَمع ما يشـاءُ وينظرُ }
\end{aligned}
$$

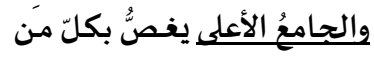

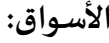

$$
\begin{aligned}
& \text { وتكثر الأسواق في قرطبة، وقد كانت مَعْلمًا لها. يقول: } \\
& \text { ومسـالكُ الأسـواقِ تشـهـدُ أنَّها }
\end{aligned}
$$

3. دلالات مكانية محايدة:

كما كان ثمة توظيف لألفاظ ذات دلالات مكانية محايدة، لا تلتزم بزمان أو مكان معينين، فهي ألفاظ مستمرة دائمة قديمًا

$$
\text { وحديثًا، وتتمثل في: }
$$$$
\text { الداروالديار: }
$$

وكثيرًا ما ورد ذكر الديار في الموروث الشعري، وهي تأتي للدلالة على المكان الذي يحل فيه الإنسان. فهي مقره وقراره، ومحطه

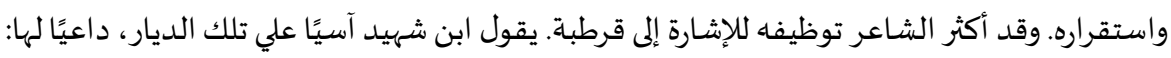

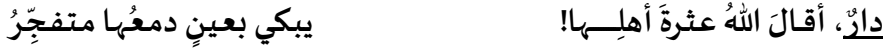

$$
\begin{aligned}
& \text { وتأتي في سياق إظهار الحنو عليها، والشفقة لما ألم بها. يقول: } \\
& \text { جَرتِ الخطوبُ على محلِّ ديارهمِ }
\end{aligned}
$$

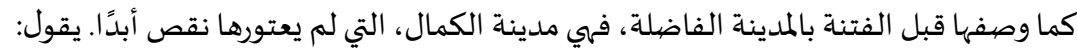

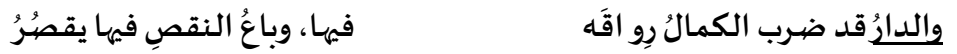

كما جاءت في سياق التعبير عن القهر والظلم، وذلك حين صارت قرطبة محطًا للظلم، وموطئًا للغبن، ومبعثا للألم. يقول:

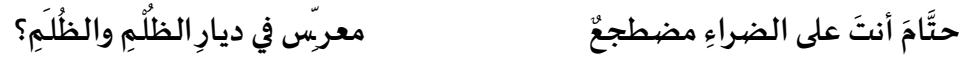

وكثر استخدام كلمة أرض، منكرةً أحيانًا، مشيرًا بها إلى قرطبة، مظهرًا فخره بها، وشفقته عليها. يقول:

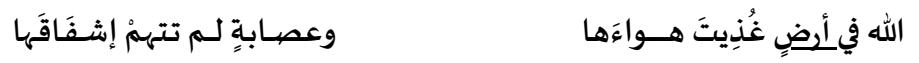

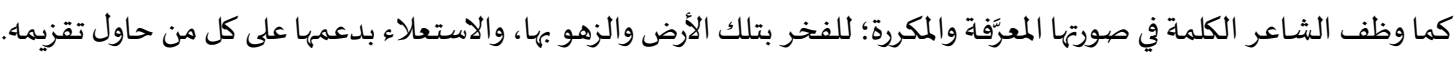

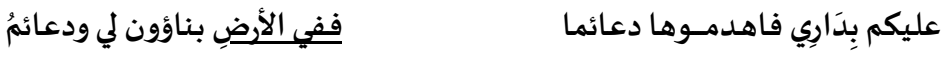

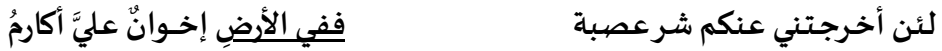

كما وردت كلمة ناحية للإشارة إلى ما لحق بالناس من فرقة وتمزق؛ فقد صارت النواحي ملتقاهم، بعد أن كانت مكانًا للانزواء،

$$
\begin{aligned}
& \text { في كـلِّ ناحيةِ وبـادَ الأكثر } \\
& \text { متفطـــر لفِر اقِهـا مُتَحَحِّر }
\end{aligned}
$$$$
\text { جَسارَ الزمانُ عليهمُ فتفرَّقوا }
$$

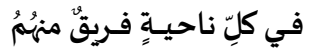


منزل:

كذا تأتي كلمة منزل لتشير إلى المكان الذي ينزل فيه الإنسان ويحل، وقد أشار بها الشاعر إلى تبدد قرطبة، وضياعها، وتفرق أهلها،

وتمزق شملهم. يقول:

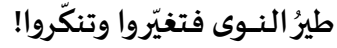

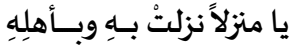

خامسًا: الموسيقى

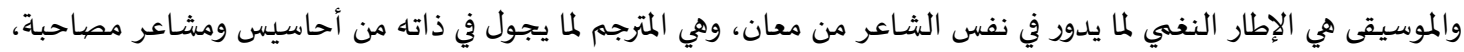

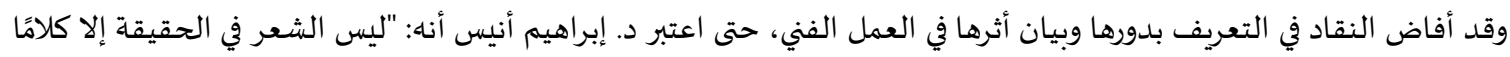

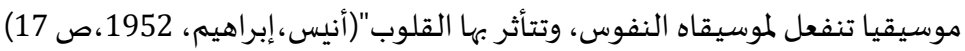

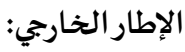

ويقصد به: "الموسيقى التي تتألف من ارتباط الألفاظ مع بعضها البعض في البيان العربي، وتشكل الإيقاع العام للجملة أو البيت،

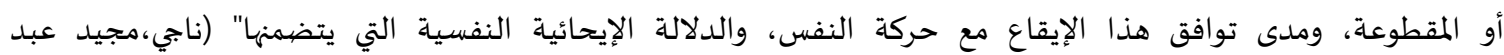

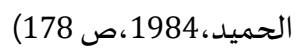

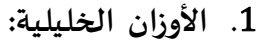

والوزن عند ابن رشيق: "أعظم أركان الشعر وأولاها به خصوصية" (القيرواني، ابن رشيق،1972، 197/1 134/1)، وعند قدامة الشعر:

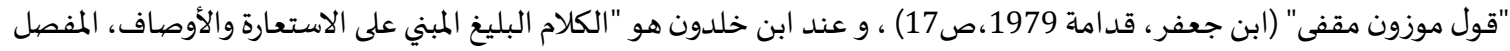

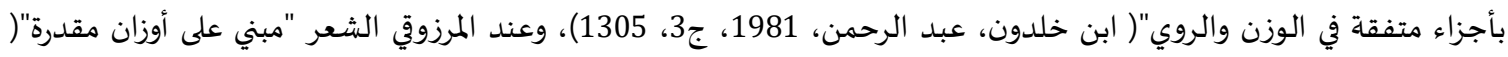

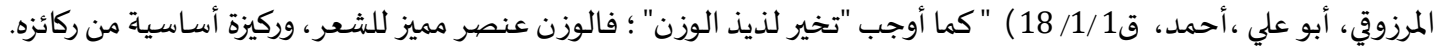

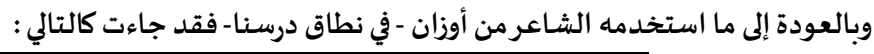

\begin{tabular}{|c|c|c|}
\hline الوزن المصاحب & رقم القصيدة & مسهى القصيدة \\
\hline الكامل & 28 & وصف ما أصاب قرطبة \\
\hline 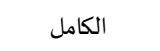 & 49 & مدح يحيى المعتلي \\
\hline الطويل & 63 & عزمه على الخروج من قرطبة \\
\hline البسيط & 68 & شكوى المستعين \\
\hline المتقارب & 77 & وصف قرطبة وعشقه لها \\
\hline
\end{tabular}

وكما هو واضح فقد مال الشاعر إلى توظيف الأبحر الطويلة - مثله مثل غيره من الشعراء -، وقل إيراده للبحور القصيرة الراقصة

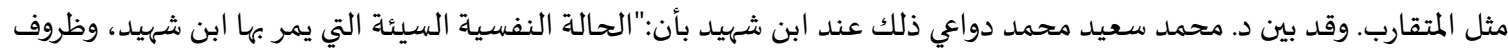

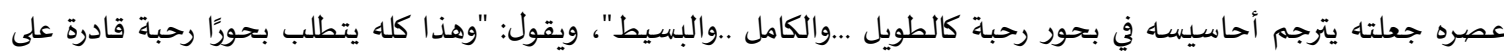

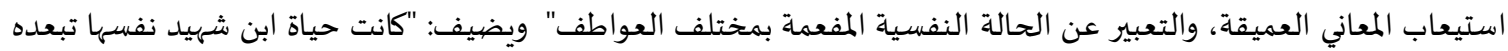
عن الموضوعات التي يتطلب التعبيرعنها بحورًا راقصاة سريعة" ( محمد ، محمد سعيد، 1988 )

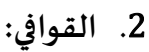
وقد التزم الشاعر في قصائده القوافي الموحدة، وهي كما عرفها د. إبراهيم أنيس: "عدة أصوات تتكرر في أواخر الأشطر أوالأبيات من أنسات

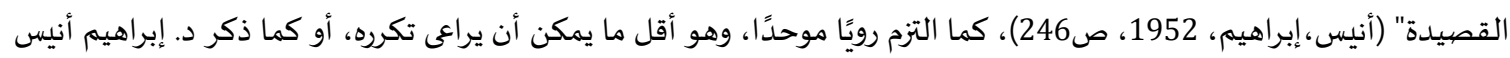

\begin{tabular}{|c|c|c|c|}
\hline نوع الروي & 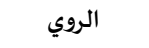 & رقم القصيدة & مسهى القصيدة \\
\hline مطلق & الراء المضمومة & 28 & وصف ما أصاب قرطبة \\
\hline 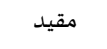 & القاف & 49 & مدح يحيى المعتلي \\
\hline مطلق & الميم المضهمومة & 63 & عزمه على الخروج من قرطبة \\
\hline مطلق & الميم المكسورة & 68 & شكوى المستعين \\
\hline مقيد مقد & 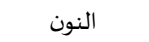 & 77 & وصف قرطبة وعشقه لها \\
\hline
\end{tabular}

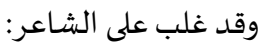

استخدم روي "حروف شائعة"، ممثلة في حروف (الراء/ الميم/ والنون)، وهي من "أسهل الكلمات نطقا"( أنيس، إبراهيم،

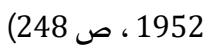


كما قل استخدامه للحروف "متوسطة الشيوع " ( أنيس، إبراهيم، 1952) ، ممثلة في (حرف القاف). توظيف الروي المتحرك، وهو كما ذكر د. إبراهيم أنيس " أيسر في التلحين وأطوع "( أنيس، إبراهيم، 1952)، وهو روي يلائم حال المحزون المؤرق الذي ينشد الراحة، ويتوخى الاتزان. • ـكرار لوازم صوتية في أواخر الأبيات قبل الروي وبعده، وهو ما مثل تعميقًا لموسيقاه، ودعماً لخطاباه الشعري. ومن أمثلتها:

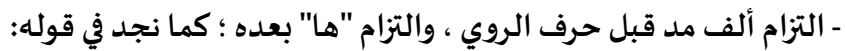

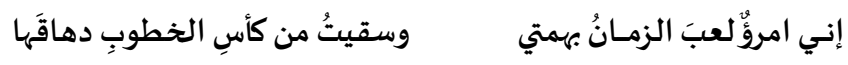

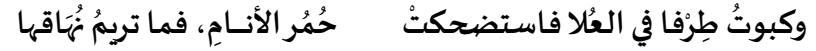

\begin{tabular}{|c|c|c|c|}
\hline الكلمة & بعد الروي & الروي & ق ق ق ق ق الروي \\
\hline دهاقها & هاء مشفوعة بألف الإطلاق & القاف & ألف مد \\
\hline ن نهاقها & هاء مشفوعة بألف الإطلاق & القاف & ألف مد \\
\hline
\end{tabular}

- التزام ألف مد قبل حرف الروي، وياء وهاء ساكنتين بعده. يقول:

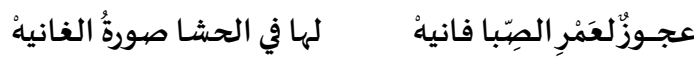

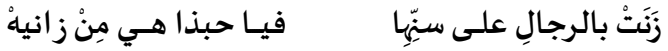

\begin{tabular}{|c|c|c|c|}
\hline الكلمة & بعد الروي & الروي & قبل الروي \\
\hline غانية & ياء + هاء ساكنة & النون & ألف مد \\
\hline زانية & ياء + هاء ساكنة & النون & ألف مد \\
\hline
\end{tabular}

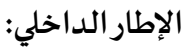
وإذا كانت المقومات الصهوتية الخارجية أو ما أسماها البعض بالمقومات الصهوتية الإجبارية "، (القاسمي، محمد عبد الله، 2010،

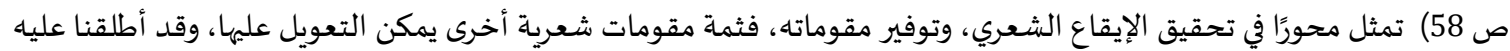

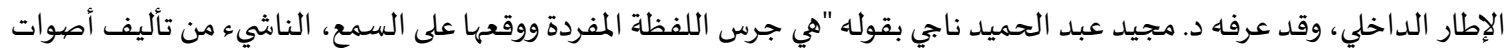

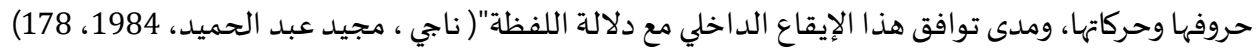
يقول الباحث مشيرا إلى الدور الذي تقوم باه التكرارات الصهوتية الداخلية في أداء المعاني: "التكرارات الصيوتية الاختيارية وكل أنواع البديع اللفظي ليس صيغًا تالية يؤتي بها للتزيين والتحسين، وإنما هي جوهرية في لغة الشاعر، لا لا تتحقق المادة الشعرية إلا بها

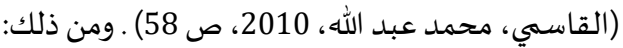

وهو تكرار صوتي، عرفه ابن رشيق بأنه: "ما كانت عروض البيت فياه تابعة لضربه، تنقص بنقصه وتزيد بزيادته" "( القيرواني، ابن 1972،

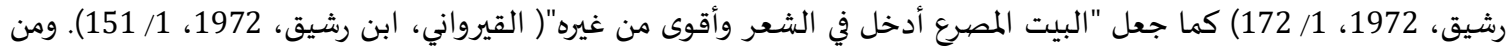

\section{فَمَن الذي عن حالها نَسْتَتْبْرُ؟}

ما في الطلولِ من الأحِبَّةِ مُخحِِِ

أمثلته:

$$
\begin{aligned}
& \text { أرى أعينا ترنو إلىى كــأنما } \\
& \text { 2. - 2 التكرارات الصهوتية: } \\
& \text { وقد شاع تكرار حروف بعينها في ثنايا القصيدة، ومن أمثلتها: } \\
& \text { • تكرارحرفي القاف والعين في قوله: }
\end{aligned}
$$

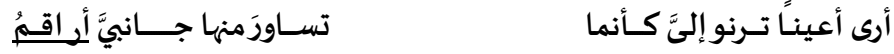

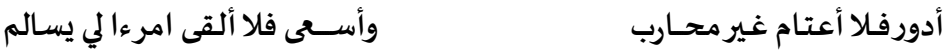

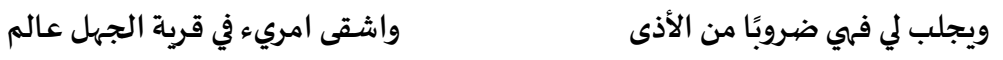




$$
\begin{aligned}
& \text { فتسى عربي تزدريه أعـاجــم } \\
& \text { وأوجـع مظلوم لقـلب وذي حسجى } \\
& \text { لقد ســـفهت تلك الحلوم الزواعم } \\
& \text { غنيتم،على ما تزعمون عن الورى } \\
& \text { إذا زال عن ريسش الجنـاح القوادم }
\end{aligned}
$$

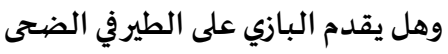

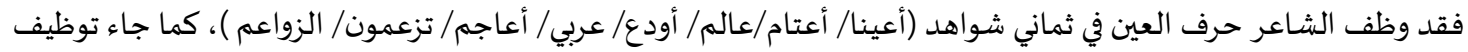

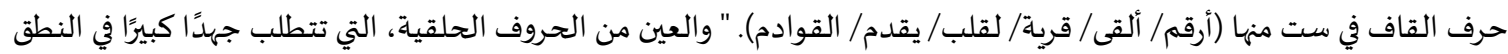
بها، كما أن حرف القاف "أنسب الحروف للمعاني العنيفة"( أنيس، إبراهيم، 1952، صرف 35) )، وهو ما لائم حالة الغضب التي اكتنت في

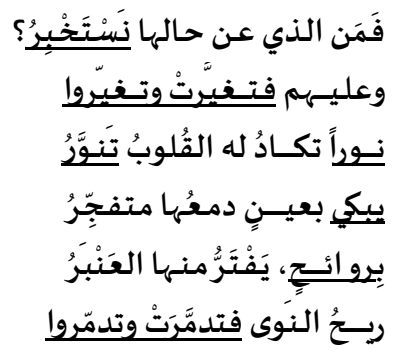
نفس الشاعر، وعبرت عن معانياء تكرار كلمات بعينها. نحو قوله:

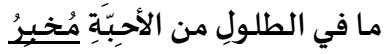

$$
\begin{aligned}
& \text { جَرتِ الخَطوبُ على مححلِّ ديـارهم }
\end{aligned}
$$

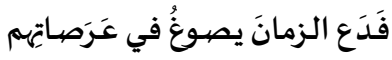

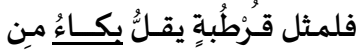

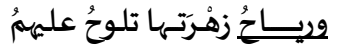

$$
\begin{aligned}
& \text { يا جــــةً عصــفتُ بها وبأهلِها }
\end{aligned}
$$

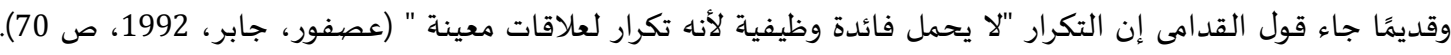
والحقيقة أن المشابهة الحرفية الطباعية في حد ذاتها هي - ولا شك- جرس يعمِّق، وتكراره إنما هو إلحاح على الإقرار بحالة نفسية

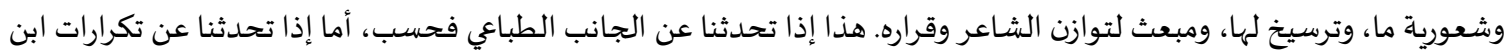

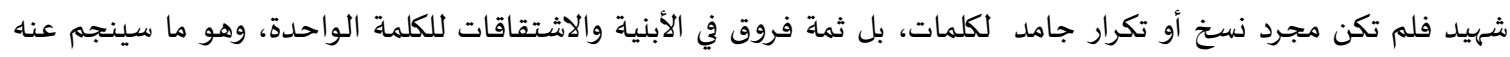

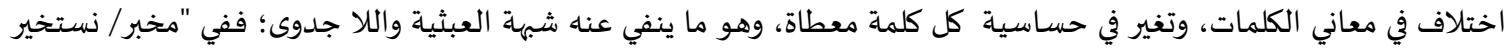

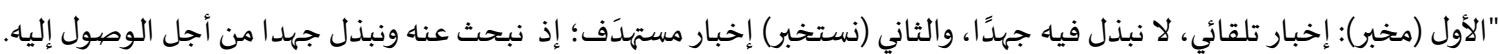

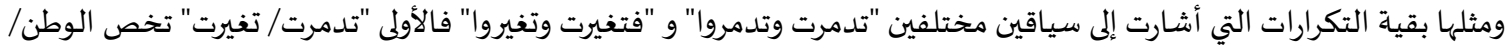

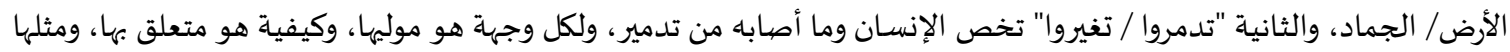

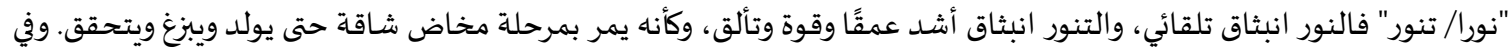

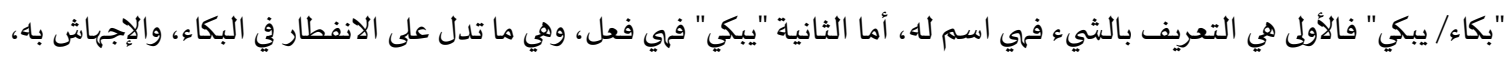

وهوما يشي بالألم والشـدة. فـ" التكرير لا يقتصر على دراسـة البعد الصوتي...وإنما يتسع ليشم ل المستوى الصيوتي والمستوى الدلالي".

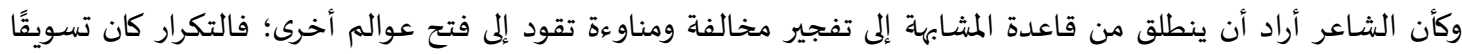

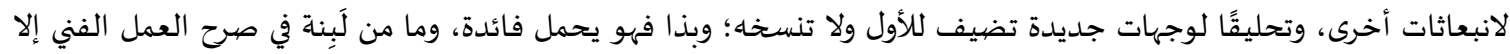

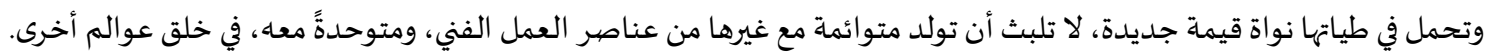

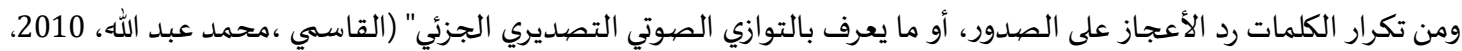

كما جاء في قوله:

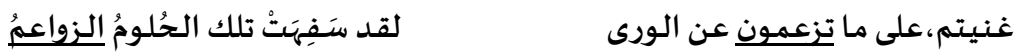

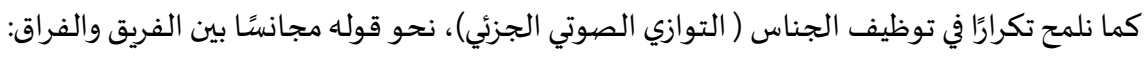
في كلِّ ناحيةٍ فيقّ منههُ

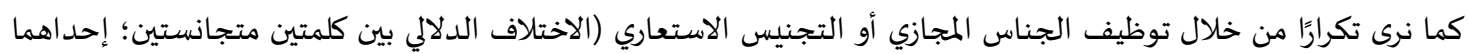
حقيقياة وثانيهما مجازية) أيضيا في قوله:

\begin{tabular}{|c|c|}
\hline من كلِّ ناحيةٍ إليها تنظرُ & لـاهَ كانت عـينُ كُلـلِ كَرامَةٍ \\
\hline
\end{tabular}

$$
\text { ففي الأرضِ بناؤون لي ودعائمُ }
$$$$
\text { عليكم بداري فاهدموها دعائمَا }
$$$$
\text { فالأولى دعائم مادياة، والثانية معنوية. }
$$

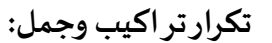

ومن التكرار أيضًا ما كان تكرارًا للجمل والتراكيب. ومنها قوله في قرطبة: 


$$
\begin{aligned}
& \text { أبـامَكان الأمرُفهيها واحداً } \\
& \text { أبـاجَ كانت كفُّ كلِّ سلامةٍ } \\
& \text { والجمل المكررة تشي باللهفة والحسرة على ماكان، والحزن والأسى على ما آل إليه حالها. } \\
& \text { ومنه تكرار الجمل العكسية، ونراه في قول الشاعر: }
\end{aligned}
$$

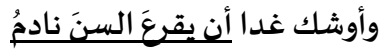

$$
\begin{aligned}
& \text { وما قرعت سـني عليكم ندامةً }
\end{aligned}
$$

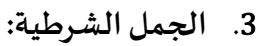

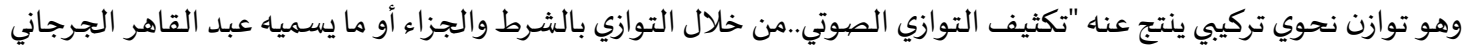

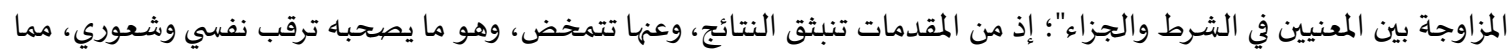

$$
\text { لـتقرعَنَّ على السنَ مِنْ نَدَمِ }
$$

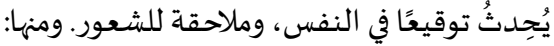

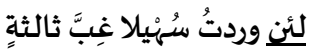

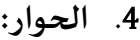

وقد أسهم الحوار في تعميق الموسيقى النفسية في أبيات أخرى، وهو ما ينتج إيقاعا "يعكس حركات النفس العميقة، ويسهم في

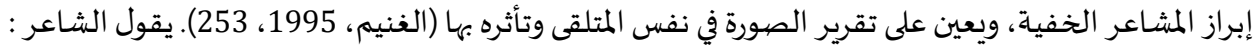

$$
\begin{aligned}
& \text { أشَكو إلهيها الهوى حِلْوَا من النِّعَمِ }
\end{aligned}
$$

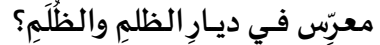

$$
\begin{aligned}
& \text { برءٌ من الشـوقِ أو برءٌ من العدمِ } \\
& \text { فقلت: إني لأستحيبي بني الحَكَمِيمِ }
\end{aligned}
$$

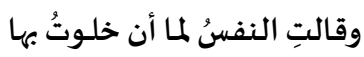

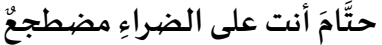$$
\text { وفي السُّرى لك لو أزمعتَّ مُرتحلَا }
$$$$
\text { ثم استمرت بفضلِ القولِ تُنْهِينيني }
$$

فالموسيقى كانت إحدى وسائل الشاعر في التعبير، كما اتسمت بالقدرة على صياغة خطاب أكثر مصداقية وتلاؤمًا مع مشاعره

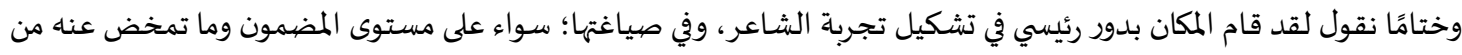

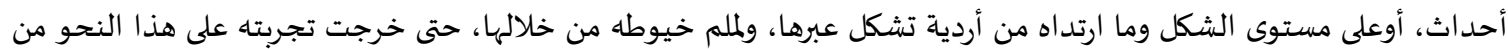

1. الجرجاني ، عبد القاهر (1976). أسرار البلاغة في علم البيان، مصر. مكتبة القاهرة . 2. 3. جعفر، قدامة (1979). نقد الشعر. ط الشع 3. القاهرة. مكتبة الخانجي.

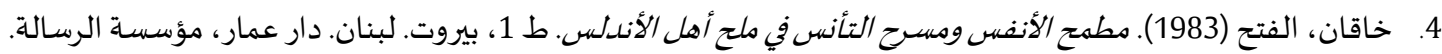

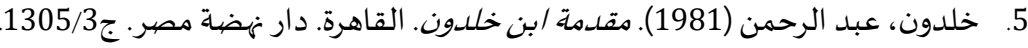

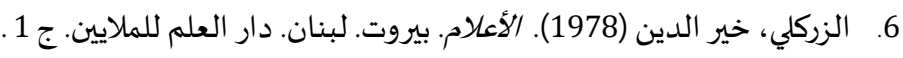

7.

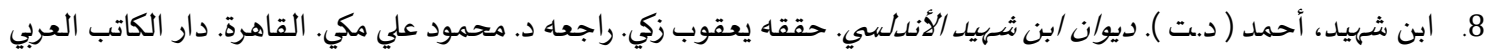
للطباعة والنشر.

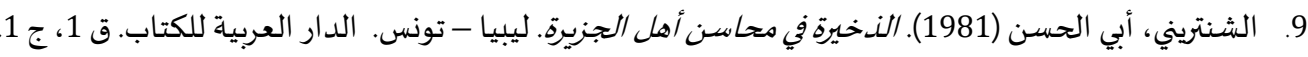

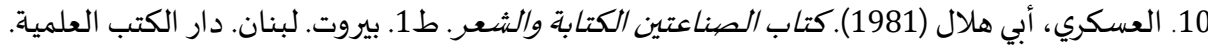

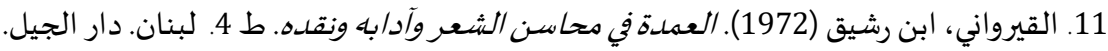

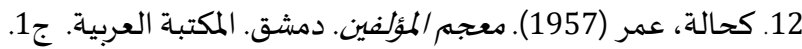

13. الممزوقي، أبي علي أحمد (1967). شرح ديوان الحماسة. ط 2. القاهرة. دار التأليف والترجمة والنشر. ق1 
14. المصري، ابن منظور (1988). لسان العرب. قدم له عبد الله العلايلي. بيروت. دار الجبل. ثانياً: المراجع:

1. أنيس، إبراهيم (1952). موسعقى الشعر. ط 5 ـ مصر. مكتبة الأنجلو المصرية. 2.

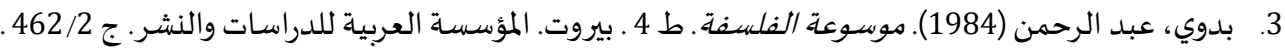

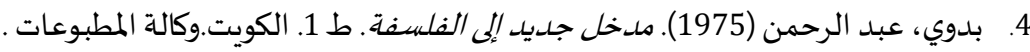

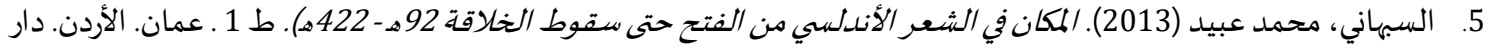
غيد اء للنشر والتوزيع.

6. الطربولي، محمد عويد (2012). المكان في الشعر الأندلسي من عصر المرابطين حتى نهاية الحكم العربي ( 484ـ 897هـ). ط1 ، 1 ـ

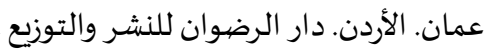

7. 8. الغنيم، إبراهيم عبد الرحمن (1995). الصيورة الفنية في الشعر العربي مثال ونقل. القاهرة. الشركة العربية للنشر. 9. قاسم، عدنان حسين (2000). التصيوير الشعري (رؤية نقدية لبلاغتنا العربية). ط 1. القاهرة. الدار العربية للنشر والتوزيع. 10. القاسمي، محمد عبد الله (2010). التكرارات الصوتية في لغة الشعر. الأردن. عالم الكتب الحديث. 11. كحلوش، فتحية. (2008). بلاغة المكان : قراءة في مكانية النص الشعري. بيروت لبنان. دار الانتشار العربي. 12. ناجي، مجيد عبد الحميد (1984). الأسس النفسية لأساليب البلاغة العربية. مصر. المؤسسة الجامعية للدراسات وللنشر.

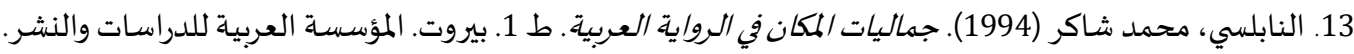
14. الكندي، أبي يوسف يعقوب (1978). رسائل الكندي الفلسفية. ط 2. القاهرة. دار الفكر العربي. مكتبة الخانجي. 15. محمد، محمد سعيد (1988). ابن شهيد الأندلسي أديباً وناقداً. طرابلس. منشورات السيات جامعة سبها. ثالثاً: الدوريات:

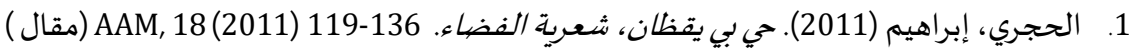

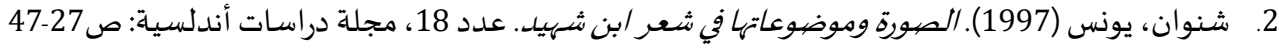
رابعاً: هيئات ومججامع: 1. المعجم الوسيط، مكتبة الشروق الدولية، 1425هـ 2004م . ط4 ، الإدارة العامة للمعجمات وإحياء البحوث. 
المجلة الدولية للدراسات اللغوية والأدبية العربية

International Journal for Arabic Linguistics and Literature Studies (JALLS)

\title{
The place in the poetry of ibn Chouhaid El Andaloussi (Cordoba as a Model)
}

\author{
Iman Anwar Hassan Aly \\ $\mathrm{PhD}$ in Andalusian Literature, Egypt \\ emaanhassan615@gmail.com
}

Received : 21/3/2021 Revised : 26/5/2021 Accepted : 27/6/2021 DOI : https://doi.org/10.31559/JALLS2021.3.2.2

\begin{abstract}
The place has an impact on man in general, and on the poet in particular; Whether in his visible words, which he lived through and knew all its details, or the positive and negative feelings, he accompanied him through his life journey, that these places produced.

Ibn Chouhaid El Andaloussi is one of the most prominent poets of Cordoba who lived two revealing periods; As he expressed to us - through his poetry - the features of life in Cordoba in its ease, prosperity and stability. He also expressed the period of adversity and the resulting displacement of people and the ruin of life and urbanism.

The research represented an attempt to investigate the impact of Cordoba on the psyche of the poet, which appeared in his poetry in two formats: one of them: Cordoba, the past and the present, and the second: Cordoba, the beloved place and the hated place.

These visions begged tools and means that could carry the poet's message and create an appropriate poetic discourse; The metaphor and the metonymy were pillars in the understanding of the poet's meanings, embodiment of his experience, pathetic fallacy, and inspiration by it. Drawing visual, auditory, and other images was a means of connecting the experience with the perceived world and mobilizing feelings to bear the message. The performance embellishments represented in the Binary Oppositions (Antithesis and Antonym), and other embellishments, carried the suffering of the poet and embodied his struggle.

The poet's culture reflected a spatial language with multiple levels, and his music - with its diversity of tones and the suitability of its music - seemed to be better able to absorb the finer details of the experience, reveal it, and express it.
\end{abstract}

Keywords: Place; imagination; poetic image; metaphor; embodiment; pathetic fallacy; metonymy.

\section{References:}

1. 'sfwr, Jabr. (1992). Alswrh Alfnyh Fy Altrath Alblaghy Walnqdy. T 3. Byrwt. Almrkz Althqafy Al'rby.

2. Anys, Ebrahym (1952). Mwsaqa Alsh'r. T 5. Msr. Mktbh Alanjlw Almsryh.

3. Bashlar, Ghastwn (1987). Jmalyat Almkan. T 3. Byrwt. Alm'ssh Aljam'yh Lldrasat Walnshr Waltwzy'.

4. Bdwy, 'bd Alrhmn (1984). Mwsw't Alflsfh. T 4. Byrwt. Alm'ssh Al'rbyh Lldrasat Walnshr. J 2/462.

5. Bdwy, 'bd Alrhmn (1975). Mdkhl Jdyd Ela Alflsfh. T 1. Alkwyt.Wkalh Almtbw'at.

6. Alghnym, Ebrahym 'bd Alrhmn (1995). Alswrh Alfnyh Fy Alsh'r Al'rby Mthal Wnqd. Alqahrh. Alshrkh Al'rbyh Llnshr.

7. Khlwsh, Fthyh. (2008). Blaghh Almkan: Qra'h Fy Mkanyh Alns Alsh'ry. Byrwt Lbnan. Dar Alantshar Al'rby.

8. Alkndy, Aby Ywsf Y'qwb (1978). Rsa'l Alkndy Alflsfyh. T 2. Alqahrh. Dar Alfkr Al'rby. Mktbt Alkhanjy. 
9. Mhmd, Mhmd S'yd (1988). Abn Shhyd Alandlsy Adybaan Wnaqdaan. Trabls. Mnshwrat Jam't Sbha.

10. Alnablsy, Mhmd Shakr (1994). Jmalyat Almkan Fy Alrwayh Al'rbyh. T 1. Byrwt. Alm'ssh Al'rbyh Lldrasat Walnshr.

11. Najy, Mjyd 'bd Alhmyd (1984). Alass Alnfsyh Lasalyb Alblaghh Al'rbyh. Msr. Alm'ssh Aljam'yh Lldrasat Wllnshr.

12. Qasm, 'dnan Hsyn (2000). Altswyr Alsh'ry (R'yh Nqdyh Lblaghtna Al'rbyh). T1. Alqahrh. Aldar Al'rbyh Llnshr Waltwzy'.

13. Alqasmy, Mhmd 'Ebd Allh (2010). Altkrarat Alswtyh Fy Lght Alsh'r. Alardn. 'alm Alktb Alhdyth.

14. Alsbhany, Mhmd 'byd (2013). Almkan Fy Alsh'r Alandlsy Mn Alfth Hta Sqwt Alkhlaqh 92h - 422h). T1. 'man. Alardn. Dar Ghyda' Llnshr Waltwzy'.

15. Altrbwly, Mhmd 'wyd (2012). Almkan Fy Alsh'r Alandlsy Mn 'sr Almrabtyn Hta Nhayh Alhkm Al'rby (484897h). T1, 'man. Alardn. Dar Alrdwan Llnshr Waltwzy'. 